\title{
Risk to Pollinators from the Use of Chlorpyrifos in the United States
}

\author{
G. Christopher Cutler, John Purdy, John P. Giesy, \\ and Keith R. Solomon
}

\section{Introduction}

Pollinators are crucial species of almost all natural and artificial terrestrial ecosystems (Garibaldi et al. 2013; NAS 2007). While most of the world's food supply, including important crops such as cereals, are mainly wind pollinated, more than three-quarters of angiosperms rely on animals for pollination and approximately $75 \%$ of the leading global fruit-, vegetable-, and seed-crops depend at least partially on animal pollination (Klein et al. 2007). Most animal pollination is done by insects, particularly bees. In the United States (U.S.) and Canada, the production of crops that require or benefit from pollination by insects is large. It is estimated that the pollination services of the European honey bee, Apis mellifera L. (Apidae), are worth over $\$ 15$ billion annually to U.S. agriculture, and the value of non-Apis pollinators to production of crops is estimated to be over $\$ 11$ billion (Calderone 2012; Morse and Calderone 2000). In addition to helping ensure a diverse supply of food for humans, pollination plays a critical role in providing the basis for essential ecosystem productivity and services (Kevan et al. 1990; Kevan 1999).

\footnotetext{
G.C. Cutler $(\square)$

Department of Environmental Sciences, Faculty of Agriculture,

Dalhousie University, P.O. Box 550, Truro, NS B2N 5E3, Canada

e-mail: chris.cutler@dal.ca

J. Purdy

Abacus Consulting, Campbellsville, ON, Canada

J.P. Giesy

Department of Veterinary Biomedical Sciences and Toxicology Centre,

University of Saskatchewan, 44 Campus Dr., Saskatoon, SK S7N 5B3, Canada

K.R. Solomon

Centres for Toxicology, School of Environmental Sciences, University of Guelph,

Guelph, ON, Canada
} 
There is concern about potential adverse effects of pesticides on pollinators (EFSA 2012; NAS 2007). Chlorpyrifos (CPY; CAS No. 2921-88-2) is an organophosphorus insecticide and acaricide that is widely used in agriculture and horticulture in the U.S. and other countries to control a wide variety of foliage- and soil-borne insect pests on a variety of food and feed crops (Solomon et al. 2014). Many of the agro-ecosystems where CPY is used contain populations of managed and wild pollinators. In some of these, such as almonds, citrus fruits, and cranberries, pollinators play a critical role in the production of the crop being protected with sprays of CPY. Other crops, such as soybean and corn, which are treated with CPY, do not directly rely on pollinators for production because they are mainly pollinated by wind, but can nonetheless serve as a source of forage for multiple species of pollinators during parts of the season. In addition to food (pollen and/or nectar), pollinators might also obtain nesting materials and occupy nesting sites in habitats exposed to CPY.

In this study, the risk posed by use of CPY to insects that serve as pollinators was assessed. Patterns of use of CPY that are currently registered in the U.S. and Canada were the main focus (Solomon et al. 2014), but tests with formulations used in other countries were considered when relevant data from the U.S. were lacking. Because microencapsulated formulations are not used in the U.S., they were excluded from the assessment. Bees were the focal taxa but other groups of insects were also considered when data were relevant and available, particularly where they are used as surrogate species in regulatory risk assessments. Non-insect pollinators were not considered. Most studies and scenarios explored for the risk assessment were concerned with agricultural systems, but patterns of use of CPY in horticulture and landscaping, such as turf were considered.

\section{Problem Formulation}

The central question considered in the problem formulation was: Is there sufficient exposure of pollinators to CPY and/or its degradate, chlorpyrifos oxon (CPYO), to present a risk of widespread and repeated mortality or biological impairment to individuals or populations of pollinators? This question forms the basis for the detailed development of the risk assessment in the following sections.

\subsection{Use Patterns of Chlorpyrifos: Pollinator Considerations}

The uses and properties of CPY are discussed in detail in a companion paper (Solomon et al. 2014). Chlorpyrifos is used to control a wide variety of economically important insect pests in a large number of agricultural and specialty application scenarios throughout the U.S. Several granular and sprayable formulations of CPY are currently marketed in the U.S. and Canada, including Lorsban Advanced ${ }^{\circledR}$ and Lorsban $^{\circledR} 15 \mathrm{G}$ for agriculture, and Dursban ${ }^{\circledR} 50 \mathrm{~W}$ for horticultural uses on trees, 
turf, and ornamental plants. Chlorpyrifos can be applied on foliage, tree bark or soil as a pre- or post-emergent spray in water to control insects or mites. It may also be applied to soil as a spray or as granules to control soil-dwelling insect pests. Maximum single application rates range from 1.12 to $4.5 \mathrm{~kg} \mathrm{CPY} \mathrm{ha}^{-1}$ for granular products and 0.53-6.27 kg CPY ha ${ }^{-1}$ for spray application. Multiple applications of the granular or flowable formulations are allowed on many crops. There are many crops that receive treatment around planting time, post-harvest or during dormancy. For crops such as apple, applications of CPY are delayed until after bloom, and as noted previously, no application is permitted when bees are actively foraging (Solomon et al. 2014).

Chlorpyrifos is widely used on corn, soybeans and wheat in the corn belt that extends from Quebec through the Midwestern U.S. to Manitoba. In the Great Plains regions of North America the main uses are on alfalfa and sunflower. In California, Florida, and Georgia, CPY is used on vegetables, citrus, and tree nuts (Gomez 2009). Other crops treated with CPY include cotton, cranberries, sorghum, strawberries, peanuts and wheat. Some of these crops are highly or partially dependent upon pollinators, or are utilized as forage or nesting material for pollinators (e.g., alfalfa leaf cutting bees). The importance of pollinators in production of tree fruit is well recognized (NAS 2007). For example, it is estimated that over $60 \%$ of honey bee colonies in the U.S. are used each year for pollination of almonds (Carman 2011). Cotton and soybeans are not critically dependent on pollinators, but bees will forage readily on the flowers of these crops (Berger et al. 1988; Rhodes 2002) and on extrafloral nectaries of cotton (Willmer 2011).

\subsection{Scope of the Assessment}

The potential for exposure of pollinators to CPY is recognized. Since the primary insect pollinators are bees (superfamily Apoidea), labels for CPY products include warnings not to apply the product or allow it to drift to flowering crops or weeds if bees are visiting the treated area, and advise users to inform local beekeepers prior to application if hives are in or adjacent to fields to be treated. Labels describing restrictions on use and best application practices also include instructions to minimize spray drift to reduce harmful effects on bees in habitats close to the application site (Solomon et al. 2014). For this reason, adverse effects due to negligence or actions contrary to precautions specified on the label were not included in this assessment. It is assumed that applications are made by trained applicators and that all instructions on the label are followed. This assessment focused on incidental exposure during applications to crops listed on the current labels under conditions specified by the labels. A search for documented incidents of harm to commercial beehives from CPY was also conducted through the USEPA and the Health Canada Pest Management Regulatory Agency (PMRA).

Because bees are considered the dominant animal pollinators and are prominent in agricultural landscapes (NAS 2007), toxicity data used in the risk assessment focused mainly on bees. There are more than 17,000 species of bees worldwide 
(Michener 2007) and it was not possible to obtain data for all species. Searches of databases incorporated 'chlorpyrifos' with the words such as 'pollinator', 'bee', 'Apis', 'Bombus', 'Megachile', and 'Osmia'. The later four are major bee genera that exist in the wild and are managed by humans in agricultural settings, and thus are most likely to have associated data on toxicity of CPY to bees. Family names of major bee families, such as 'Apidae', 'Megachilidae', Andrenidae', 'Halictidae', and 'Colletidae' were used. Other potentially important pollinators include the dipteran families Bombyliidae (bee flies) and Syrphidae (hover flies), but no reports examining effects of CPY on these taxa were found. Other insect taxa can pollinate, but generally do so adventitiously, less frequently, and are generally not considered important pollinators of crops in the U.S. to which CPY is applied. For estimates of exposure, data from semi-field or field experiments with leaf-dwelling species was considered a potential source from which to develop point estimates of contact exposure for foliar-applied products (Fischer and Moriarty 2011), since these species may be considered surrogates for bees. Because data on toxicity of CPY to non-Apis pollinators were rare, studies were considered that assessed effects of CPY on certain other arthropod taxa that have also been shown to be suitable surrogate species for non-Apis bees (Candolfi et al. 2001; Miles and Alix 2012).

Data were collected from sources listing 'chlorpyrifos' or 'chlorpyrifos-ethyl' as the active substance; both are common names of $O, O$-diethyl $O$-3,5,6-trichloropyridin2-yl phosphorothioate. The insecticidal degradate chlorpyrifos-oxon (CPYO) was also considered. Exposure and effects data for 'chlorpyrifos-methyl' ( $O, O$-dimethyl $O-3,5,6$-trichloro-2-pyridinyl phosphorothioate) - a different compound-were not included in the risk assessment. The assessment of risk was primarily focused on evaluating potential impacts of typical CPY formulations currently registered for crop production in North America on bee pollinators.

\subsection{Conceptual Model}

Adverse effects on ecosystems result from the interaction of a stressor, in this case CPY and its degradation products, with receptors of concern, such as individual pollinators, hives, nests, or populations. The degradation product of concern for CPY is CPYO, which is also the activated biologically-active product of CPY (Solomon et al. 2014). Other degradates of CPY are of minimal risk to pollinators. A conceptual model can be constructed to illustrate potential routes of exposure during agricultural use, and the taxa and life stages potentially affected (Fig. 1). The conceptual model shows the scope of the risk assessment, guides its development, and illustrates the relationships among the potential exposure pathways. Previous conceptual models for assessments of effects of agricultural chemicals on pollinators have noted the need to quantify exposure within and outside the treated area and to consider the behavioral and biological traits of pollinators (Barmaz et al. 2010).

The conceptual model was developed for foliar spray or granular soil-applied treatments of CPY. For pollinators, exposure is primary if it is to the initial exposed 


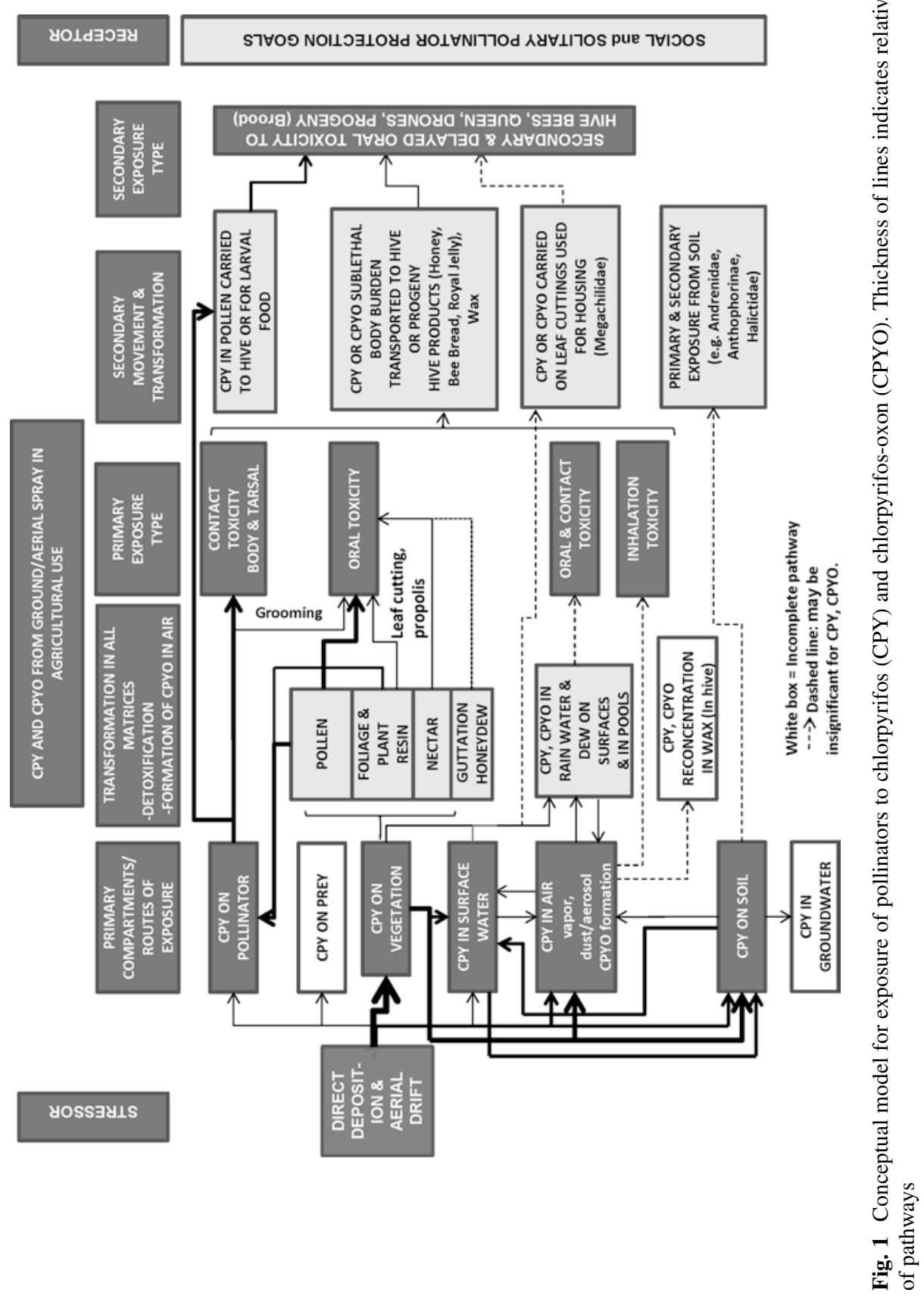


individual (e.g., a foraging worker), or secondary if other adults or offspring in a hive or nest are subsequently exposed. Potential exposures through various compartments of air, water, soil, and vegetation are complex and interconnected. The pathway of exposure via water was divided into precipitation, surface water, rain and dew on leaves, and guttation. The vegetation component was comprised of foliage, pollen, honeydew, and nectar.

Although other pollinators were considered to the extent possible based on available literature, honey bees were the main focus of this risk assessment. Honey bees are the major pollinators of crops in North America, and are the subject of welldeveloped standardized methods for evaluating exposure and effects as compared to non-Apis bees. They are considered a useful surrogate for other pollinators, particularly in regulatory risk assessment. Because they forage on a wide variety of plant hosts, have a tendency to focus on specific pollen or nectar sources for extended periods, and have a greater foraging range compared with other pollinators, exposures of honey bees are widely used as a worst-case exposure scenario among pollinators (Porrini et al. 2003).

Non-Apis bee pollinators can be exposed to CPY in ways that are different from those for honey bees (Fig. 1). Most non-Apis bees are solitary nesters and use soil and/or vegetation in the construction of nests (e.g., Megachile, Osmia), or nest in soil (e.g., Andrenidae, Halictidae) (Michener 2007). The significance of these alternative routes of exposure should be taken into consideration when comparing the potential for exposure. Since most pollinators are not predators, the route of exposure via prey is considered incomplete (Fig. 1). Predators such as wasps (Vespa sp.) were excluded from the risk assessment. They are not major pollinators, fit better into a conceptual model for higher trophic levels, and would be protected if the major pollinators are not at risk.

The major potential routes of exposure are shown in the conceptual model in Fig. 1. The thickness of the arrows in the model approximates the relative importance of each pathway. The conceptual model shows the pathways for distribution of applied material during and after application into the environmental compartments that may lead to exposure of pollinators to CPY. Degradation and dissipation occur in all compartments and there can be some redistribution of material between compartments.

Primary routes of exposure. As mentioned above, labels for sprayable products containing CPY caution against application on blooming crops or drift onto weeds or surface water when bees are actively foraging. By eliminating direct contact with airborne spray droplets or contact with spray liquid on surfaces before it dries, these restrictions represent a major reduction in potential for primary exposure of pollinators, both in the treated area and in the downwind areas where spray drift might occur. Exposure to CPY vapor is insignificant due to the low vapor pressure (Solomon et al. 2014), and CPY has no appreciable vapor action. The pathways for direct exposure of pollinators to airborne spray droplets or vapor are therefore shown as minor pathways in Fig. 1.

For granular CPY products, there should be little or no exposure via drift of dust, or deposition on foliage, pollen, or other surfaces. Chlorpyrifos is non-systemic and 
is not used as a seed treatment, so there is no contribution from seed dust during planting and there is no translocation and guttation. Volatilization of foliar residues constitutes the most significant source of airborne contamination. However, residues of CPY in air are not persistent, and maximum concentrations found in air monitoring studies were less than $250 \mathrm{ng} \mathrm{m}^{-3}$ (Mackay et al. 2014), which, when compared to the toxic dose in bees of about $80 \mathrm{ng} \mathrm{bee}^{-1}$ suggests that risks from exposure of this type would be de minimis.

Thus, the main route of direct exposure for pollinators is the uptake of CPY from plant surfaces after application. Residues of CPY applied as a spray on vegetation are mostly on foliage, which includes any non-crop flowers open during application. For example, white clover in turf or in groundcover under an orchard or areas adjacent to a treated field is very attractive to pollinators and can be in bloom during foliar application (Barmaz et al. 2010). Pollen in flowers that were open during application remains available for collection by pollinators for some time after treatment, but concentrations of pesticides in pollen and on plant surfaces will decline and become less bioavailable with time, particularly after sprays have dried. Nectar and honeydew were grouped into a sub-compartment of vegetation. Direct oral toxicity due to exposure via nectar and honeydew are incomplete or minimal because CPY is not systemic and is not taken up via roots and translocated upward through the plant (Racke 1993). Relatively smaller amounts of CPY would be expected in honey for the following reasons:

- Nectar is more protected than pollen from exposure to spray droplets by the anatomy of flowers (Willmer 2011).

- Nectar, water, and honeydew are carried internally in the "honey stomach" by bees (Gary 1975; Snodgrass 1975), where residues of pesticides are more likely to be absorbed and metabolized, reducing the amount transferred to the hive. Residues of CPY have been shown to decrease 3-fold when pollen is processed into bee bread (DeGrandi-Hoffman et al. 2013).

- CPY present in nectar would be exposed to water, which would favor hydrolysis and detoxification pathways over oxidation, and formation of CPYO (Solomon et al. 2014).

- Forager bees are initially most exposed to residues in nectar since it is ingested and those individuals could be impaired or killed by greater concentrations before returning to a hive. This potential for toxic effects before returning to a hive would be exacerbated by relatively greater loads of nectar (40-90 mg bee ${ }^{-1}$ ) compared to pollen (12-29 $\mathrm{mg} \mathrm{bee}^{-1}$ ) per foraging trip (Gary 1975).

- Residues in honey in the hive are likely the result of transfer of residues from a sublethal body burden of CPY in the adult bees from other sources, such as pollen, nectar and water.

Honey bees actively forage for water to regulate temperature of the hive through evaporative cooling, to prepare larval brood food, and for their own metabolism (Gary 1975; Winston 1987). Exposure of pollinators from large CPY contaminated bodies of water is probably insignificant since bees do not collect water from large areas of open water. The main water sources for bees are wet foliage, dew, and 
surface water from wet soil and ephemeral pools, which are accessible to bees and can be contaminated with pesticides through rain, runoff, or from soil surfaces. CPY on vegetation and in air can contribute to residues in rainwater and dew on plant surfaces that can be directly toxic, or can be returned to the hive/nest by foragers collecting water as part of the sublethal body burden (Gary 1975). If CPY is present in air, it can appear briefly in rainwater before hydrolysis occurs (Tunink 2010) or the water dries. The release of residues from surfaces of leaves following rain after a spray has dried should be limited due to the high affinity of CPY for nonpolar media (Solomon et al. 2014). No information on collection of water by non-Apis pollinators or where they obtain it was found, but scenarios for exposure of honey bees from water should be protective of non-Apis taxa, because they provide water for the hive and carry larger amounts.

Foliage and flower parts other than pollen represent a potential source of contact exposure for foraging pollinators. Leaf cutting bees (Megachilidae) may be particularly affected by dried residues of CPY on foliage since they cut and collect leaf discs for construction of their nest cells. Plant resin, e.g. from poplar buds, was included in the foliage compartment since honey bees collect small amounts of this material in making propolis. These materials could contain residues from off target drift, but propolis was considered to represent an insignificant exposure route to honey bee foragers (Fig. 1).

Soil and soil-water represent a potential pathway of exposure to CPY for pollinators that are ground nesters, or use soil in building nest cells, such as mason bees. These exposures can be from sprayable formulations or granular CPY that dissolves into soil-water.

Secondary routes of exposure. With social pollinating insects, such as honey bees and bumble bees, secondary exposure to pesticides can occur in other adults or offspring if the pesticide is brought back to the hive or nest and deposited in food or other materials, or transferred to other individuals (Fig. 1). Solitary bees such as alfalfa leafcutting bees or mason bees would not transfer residues to other adults, but larvae could be exposed orally to residues in food provisions; both larvae and eggs could potentially be exposed by contact with nesting materials that were contaminated in the field. Residues can also be excreted by honey bees in wax, which is produced metabolically and secreted by bees for construction of honeycomb. Residues in wax could originate from the sublethal body burden of CPY in bees as they produce the wax, by partitioning of CPY from contaminated pollen or nectar, and possibly by partitioning of CPY vapor from the air in the hive. As noted, CPY is not persistent in air and the maximum concentration of CPY in air is expected to be less than $250 \mathrm{ng} \mathrm{m}^{-3}$. Thus transfer of CPY from air into wax in the hive is likely an insignificant pathway (Fig. 1). The potential for exposure via transfer of CPY from wax is low because wax is not consumed as food and because CPY is strongly lipophilic, with a Log $\mathrm{K}_{\mathrm{OW}}$ of 5.0 (Mackay et al. 2014). This predicts that partitioning from wax into eggs, larvae, royal jelly, honey, or stored pollen is unfavorable. Wax is more likely a sink for CPY residues in the hive than a potential pathway for exposure. 
The main pathway for secondary exposure is transfer of residues in pollen or nectar into the hive or nest. With CPY, the amount of pesticide in pollen or nectar is limited to what was present on these materials in the treated area of the crop during application, since CPY is non-systemic and is not redistributed within the plant. Some plant species have flowers that provide pollen or nectar for several days after opening and these would present the highest potential for oral exposure. Secondary oral exposure from pollen is not limited to sublethal doses since foragers carry pollen externally and have the potential to bring back to the nest pollen containing lethal pesticide concentrations without being impaired. This is not likely with propolis, nectar, or water, which are carried internally. Direct transfer of residues from propolis to larvae is highly unlikely, but some hive adults can subsequently be exposed when manipulating propolis in the hive.

Potential exposure to contaminated food in the hive depends on the type and amount of food consumed by the various life stages and castes of bees. While pollen likely represents the highest risk of oral exposure, there is a decline in concentration as pollen is processed and used as food in the hive (DeGrandi-Hoffman et al. 2013). Exposure via royal jelly is expected to be minimal because of the large $\mathrm{K}_{\mathrm{OW}}$ of CPY (Mackay et al. 2014). In field-cage enclosed colonies fed almond pollen, collected from foraging bees in an orchard, the mean concentrations of CPY in bee bread and nurse bees were 32 and $8.3 \%$ of that found in the pollen, respectively, and no residues were detected in royal jelly or developing queen bees (DeGrandi-Hoffman et al. 2013). The results in this study show a reduction of at least 1,000-fold between concentrations of CPY in pollen and those in royal jelly and queen larvae. This shows isolation of the queen and larvae from exposure to CPY resulting from the social behavior of the colony, offers significant protection against potential toxicity of CPY.

As mentioned, amounts of CPY in nectar returned to a hive are expected to be less than in pollen since nectaries are less exposed than anthers (Willmer 2011), but this is still a pathway for secondary exposure. Nectar is dehydrated and digested by honey bees to make honey, which is the main source of carbohydrate for the hive. Mature honey in honey comb is capped with wax for later use, alone or mixed with stored pollen to make "bee bread", which is the major protein source for the colony (Winston 1987). Nectar can be consumed directly and is transferred between adult worker bees as food and when communicating forage sources (Butler 1975; Gary 1975). Potential secondary contact exposure of eggs and oral- and contact-exposure of larvae during the first $3 \mathrm{~d}$ of development is limited to residues released into royal jelly by nurse bees or transfer of material from beeswax. As noted above, this route is minimal for CPY. Older larvae can receive nectar, but only small amounts of pollen, and no food is offered to pupae. Larval queen bees are fed royal jelly continually and food is left in the capped cell for consumption during the pupal stage (Butler 1975; Dietz 1975). Even after emergence as an adult, the queen depends on nurse bees for food and water. This increases the isolation of the queen from exposure to toxicants in the nectar and pollen and exposure via royal jelly is considered to be less than for other food sources in the hive (USEPA 2012). Overall, in honey bees, greater amounts of pollen are consumed by nurse bees and, to a lesser extent, 
by larvae. Larger amounts of nectar or honey are consumed by wax-producing bees, brood-attending bees, "winter" bees, and foragers, with foragers consuming relatively large amounts (Rortais et al. 2005 and references therein).

For honeybees, the potential for exposure to CPY can be greater during production of bee bread by worker bees than in other activities in the colony. To make bee bread, workers break newly collected pollen balls deposited by foragers, mix the pollen with saliva and honey, and pack it into cells with their mandibles and tongue (Dietz 1975). It is possible that the appearance of dead bees in front of a hive following accidental overexposure to pesticides could be the result of these bees being exposed to a greater dose than the forager bees (Atkins 1975).

\subsection{Endpoints}

Assessment endpoints are explicit measures of the actual environmental value or entity to be protected (USEPA 1998). They are important because they provide direction and boundaries in the risk assessment for addressing protection goals and risk management issues of concern. Assessment endpoints were selected a priori based on likely pathways of pollinator exposure, patterns of use of CPY, and toxicity, as well as their ecological, economic, and societal value. For honey bees, relevant assessment endpoints are colony strength (population size and demographics) and survival of the colony (persistence), both of which have ecological relevance, are known to be affected by pesticide use, and are directly relevant to the stated management goals (Fischer and Moriarty 2011; USEPA 2012). Productivity of hive products such as honey was also considered as an assessment endpoint and is reflected in hive strength. For wild pollinators, species richness and abundance were considered to be the principle assessment endpoints. In contrast to honey bees, where the loss of a single forager has little impact on a colony as a reproductive unit, the loss of an individual bee of a solitary species represents the loss of a reproductive unit.

Measures of effects are specific parameters that are quantified as indicators of potential effects of stress that are linked to assessment endpoints (USEPA 1998). These measures are obtained from multiple levels of investigations, including laboratory dosing studies, modeling exercises, controlled field application studies, and incidents documented in the field. This approach covered all combinations of toxicity and exposure. In the laboratory, effects of pesticides on bees are mainly measured through survivorship after 24-96 h following acute topical or oral exposure, which is usually expressed as a $\mathrm{LD}_{50}$ (dose that kills $50 \%$ of the test organisms) or $\mathrm{LC}_{50}$ (the exposure concentration that kills $50 \%$ of test organisms). Acute exposures are particularly relevant for this risk assessment on pollinators since CPY exerts its toxic effects rapidly and has a relatively short half-life on vegetation $(<1 \mathrm{wk})$ and soil surfaces ( $\approx 1 \mathrm{wk})$ (Mackay et al. 2014; Racke 1993; Solomon et al. 2001).

Chronic and sublethal tests can be conducted in the laboratory but there are no formal guidelines for conducting and interpreting these toxicity tests with pollinators (Desneux et al. 2007; Fischer and Moriarty 2011; USEPA 2012), and consistent 
linkages to assessment endpoints are lacking (Alix and Lewis 2010; Fischer and Moriarty 2011). Given the limited number of such studies that were found and the high degree of variability in methods among these studies, chronic laboratory studies were not used in this risk assessment. Since the focus of this risk assessment was on endpoints and assessment measures related to survival, development, reproduction, and colony strength, studies that examined effects of CPY on pollinators using endpoints such as oxidative stress (Shafiq ur 2009) and localized cell death (Gregoric and Ellis 2011) were not included.

Available higher-tier semi-field and field-tests provide data on mortality, foraging behavior, brood development, and overall vigor. These should receive greater weight than the results of sublethal testing because the net effect of multiple stressors and modes of action are integrated into these higher-tier tests (Thompson and Maus 2007). Semi-field and field tests were an important line of evidence in this risk assessment.

The analysis conducted here consisted of four parts recommended by the USEPA Risk Assessment Framework (Fischer and Moriarty 2011; USEPA 1998, 2012): (1) characterization of the stressor; (2) characterization of potential exposures by various pathways; (3) characterization of effects in pollinator or surrogate species; and (4) risk characterization.

\subsection{Sources of Information}

Data on exposure and toxicity were mainly obtained from reports in the peerreviewed literature, the USEPA ECOTOX database (http://cfpub.epa.gov/ecotox/ quick_query.htm), and internal reports obtained from Dow AgroSciences. Peerreviewed articles were searched mainly through the ISI Web of Knowledge and SciVerse Scopus databases. Incident reports for the years 1990 to present were obtained from the Environmental Fate and Effects Division, USEPA Office of Pesticide Programs (USEPA 2013). Additional incident reports were obtained from the Health Canada PMRA.

\subsection{Risk Assessment Approach}

The risk characterization scheme applied was that used by the USEPA Office of Chemical Safety and Pollution Prevention for assessing risks of foliar sprayed pesticides to pollinators (USEPA 2012). The process is iterative, relying on multiple lines of evidence to refine and characterize risk. The scheme incorporates Tier-1 (worst case) screening-level assessments that calculate risk quotients (RQ) based on ratios of estimated exposure by contact exposure and oral uptake of CPYcontaminated nectar and pollen, and effects determined by corresponding toxicity tests. Strictly speaking, a RQ should refer to a value calculated on the basis of probabilities. European terminology favors "hazard quotient" (HQ) to represent this as a deterministic ratio. The OCSPP convention RQ was used in this document. 
If the RQ exceeded the level of concern (LOC of 0.4 for acute tests), higher-tier assessments were needed to obtain a more realistic measure of the risk of CPY to pollinators. The Tier- 2 process involved more elaborate semi-field or field studies with whole colonies, quantification of residues in pollen and nectar, and modeling. Risks of exposure to CPY through water on wet soil, such as puddles, and wet foliage from rain and dew was assessed by use of simulation models. Tier-3 tests studies were used to resolve important uncertainties identified in Tier- 1 and Tier-2 assessments. Incident reports were also considered in the Tier-3 assessment.

Honey bees have long been included in regulatory test requirements as a surrogate for pollinators as well as for terrestrial invertebrates in general (USEPA 1988), and most data on CPY in this risk assessment relate to honey bees. In studies on 21 species of non-Apis bees, $\mathrm{LD}_{50}$ values for several species are within an order of magnitude of that of the honey bee (Fischer and Moriarty 2011), suggesting A. mellifera can be a good surrogate species for other bees (Porrini et al. 2003). Toxicity data for CPY in non-Apis pollinators were used when available.

In addition, certain non-target arthropods (NTA) such as Aphidius spp. (Hymenoptera: Braconidae), Typhlodromus spp. (Mesostigmata: Phytoseiidae), and Aleochara bilineata (Coleoptera: Staphylinidae) can be useful in assessing risks to non-Apis pollinators (Miles and Alix 2012). Therefore, an attempt was made to find useful toxicity data for CPY with these non-target arthropods and their usefulness as surrogates for non-Apis bees was evaluated.

\section{Characterization of Exposures}

\subsection{General Physical and Chemical Properties and Fate}

The chemical, physical, and environmental profile of CPY (Giesy et al. 1999; Racke 1993; Solomon et al. 2001, 2014), and its environmental fate on plants, in water and in soil (Mackay et al. 2014; Racke 1993; Solomon et al. 2001), have been welldescribed by others and is not repeated here.

\subsection{General Fate in Insects}

The metabolism of CPY in animals consists of transformation and conjugation processes. When not exposed to lethally toxic doses, CPY is readily metabolized and eliminated by most insects (Racke 1993). Activation to CPYO, which is the toxic form of CPY, and deactivation to form trichloropyridinol (TCP) occur simultaneously. Conjugation of the intermediates is a precursor to excretion (Racke 1993). In cockroaches (Leucophaea maderea), imported fire ants (Solenopsis 
richteri), and European corn borer (Ostrinia nubilalis) larvae, 5.5, 25, and 30.7\% of CPY was excreted, respectively (Chambers et al. 1983; Tetreault 1985; Wass and Branson 1970).

\subsection{Tier-1 Characterizations of Exposure}

Estimates of contact exposure during spray application. CPY is applied as an insecticide and mitigation measures are required to protect pollinators. Such measures are described on product labels. Bee-kill incidents in the U.S. involving direct exposure to CPY are rare (see section on Incident Reports below), indicating that the effectiveness and level of compliance with these measures are high. Therefore, the direct contact route of exposure was not considered in the higher tier refinements of the risk assessment.

Estimates of dietary exposure. The USEPA has proposed that doses of pesticide received by bees via food can be calculated from rates of consumption of nectar and pollen estimated for larval and adult worker bees (USEPA 2012). Because toxicity data are expressed as doses $\left(\mu \mathrm{g}\right.$ CPY bee $\left.{ }^{-1}\right)$, it is necessary to convert estimated concentrations of CPY in food ( $\mathrm{mg} \mathrm{CPY} \mathrm{kg}^{-1}$ ) into doses. For honey bee larvae, the proposed total food consumption rate is $120 \mathrm{mg} \mathrm{d}^{-1}$. For adult workers, a median food consumption rate of $292 \mathrm{mg} \mathrm{d}^{-1}$ is proposed, based on nectar consumption rates of nectar-foraging bees, which are expected to receive the greatest dietary exposures among different types of worker bees (USEPA 2012). These values are conservative estimates of dietary consumption and are expected to be protective of drones and queens as well. These methods are additionally conservative in that they assume that the pesticides do not degrade in the hive. The USEPA recommends that this Tier- 1 exposure assessment covers both honey bees and other non-Apis bees (USEPA 2012).

Estimates of pesticide levels in nectar and pollen calculated by the T-REX model have been proposed (USEPA 2012). Based on upper-bound residue values for tall grass, $110 \mathrm{mg}$ CPY kg-1 nectar for an application rate of $1.12 \mathrm{~kg} \mathrm{CPY} \mathrm{ha}^{-1}$ is proposed as a conservative (high-end) estimate of dose received by bees consuming

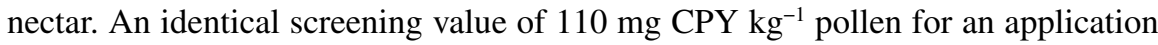
rate of $1.12 \mathrm{~kg} \mathrm{CPY} \mathrm{ha}^{-1}$ is proposed for pollen. These values assume that concentrations are distributed uniformly in the plant tissues. They are converted to an estimated dietary dose that is based on larval and adult worker bees consuming aforementioned rates of pollen and nectar (120 and $292 \mathrm{mg} \mathrm{d}^{-1}$, respectively). Therefore, the proposed dietary exposure values for larvae and adults are $12 \mu \mathrm{g}$ CPY bee ${ }^{-1} \mathrm{~kg} \mathrm{CPY} \mathrm{ha}^{-1}$, and $29 \mu \mathrm{g}$ CPY bee ${ }^{-1} \mathrm{~kg} \mathrm{CPY} \mathrm{ha}^{-1}$, respectively (USEPA 2012). Using these high-end proposed dietary exposure rates with maximum (1.05$\left.6.31 \mathrm{~kg} \mathrm{CPY} \mathrm{ha}^{-1}\right)$ and minimum (0.26-2.10 $\mathrm{kg} \mathrm{CPY} \mathrm{ha}^{-1}$ ) application rates for Lorsban 4E and Lorsban Advanced, gives estimated CPY dietary exposure esti-

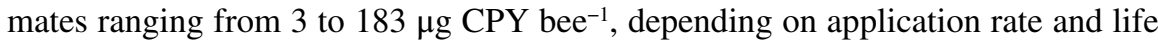
stage (Table 1). 
Table 1 Tier-1 estimates of chlorpyrifos (CPY) dietary exposure in honey bees (aggregate nectar and/or honey and pollen consumption) during foliar applications of Lorsban 4E or Lorsban Advanced at minimum and maximum application rates based on T-REX estimates of concentrations in pollen and nectar

\begin{tabular}{lll}
\hline Life stage & Minimum dose $\left(\mu \mathrm{g}\right.$ CPY bee $\left.{ }^{-1}\right)$ & Maximum dose $\left(\mu \mathrm{g}\right.$ CPY bee $\left.{ }^{-1}\right)$ \\
\hline Adult & $7.5-61$ & $30.5-183$ \\
Larvae & $3.1-25$ & $12.6-75$ \\
\hline
\end{tabular}

Estimates of post-application residual contact exposure. Post-application contact exposure for bees is mainly from exposure to residues on the surface of flowers that were open during application and remain attractive to bees after application, since they are attracted to flowers and do not typically land on leaves or other plant surfaces (Willmer 2011) (Fig. 1). An estimate of the concentration of CPY on the surfaces of plants in units of mass per unit area (e.g., $\mu \mathrm{g} \mathrm{cm}^{2}$ ) is required for comparison to the measured endpoint from standard contact toxicity tests. The USEPA guideline does not provide a Tier-1 estimate for this scenario (USEPA 2012). The Kenaga nomogram, as revised by Fletcher et al. (1994), was developed to provide an estimate of exposure on vegetation after application of a pesticide. However, the estimate is in $\mathrm{mg} \mathrm{AI} \mathrm{kg}{ }^{-1}$ fresh weight, making it unsuitable for estimates of post-application contact exposure.

\subsection{Tier-2 Characterization of Exposure}

Estimates of dietary exposure from field data. Applications of CPY outside the flowering period would not be expected to result in exposure of bees through nectar and pollen, but some flowers, including those on weeds that were open during spray application, may remain available to foraging pollinators after application, leading to both contact and dietary exposure of adult foragers.

No data on concentrations of CPY in pollen and nectar manually collected in the field were found. However, several studies screened pollen or honey collected from honey bee hives for pesticides, including CPY. A broad survey of concentrations of pesticide in samples collected from honey bee hives across 23 states in the U.S., one Canadian province, and several agricultural cropping systems during the 2007-2008 growing season was conducted by Mullin et al. (2010). The survey included both migratory hives moved to multiple crops for pollination and non-migratory hives. Of the 118 pesticides and metabolites surveyed, CPY was the most frequently found insecticide other than those used in the hive as acaricides for mite control, and the third-most detected compound in trapped pollen or beebread samples (153 of 350 samples). The mean concentration was $53.3 \pm 10.6$ (SEM) $\mu \mathrm{g} \mathrm{kg}^{-1}$ in those samples that had positive detects (Table 2). Median and 95th centile CPY pollen concentrations reported by Mullin et al. (2010) were based on calculations that included non-detections. 
Table 2 Concentrations of chlorpyrifos (CPY) detected in pollen and honey from honey bee colonies

\begin{tabular}{|c|c|c|c|c|c|c|c|}
\hline \multirow[b]{2}{*}{ Matrix } & \multicolumn{5}{|c|}{ Concentration $\left(\mu \mathrm{g} \mathrm{kg}^{-1}\right)$} & \multirow[b]{2}{*}{$\%$ of samples } & \multirow[b]{2}{*}{ Reference } \\
\hline & Mean $^{\mathrm{a}}$ & Median $^{\mathrm{b}}$ & Maximum $^{\mathrm{b}}$ & $\begin{array}{l}\text { 95th } \\
\text { centile }^{\mathrm{b}}\end{array}$ & $\mathrm{LOD}^{\mathrm{c}}$ & & \\
\hline \multirow[t]{4}{*}{ Pollen } & 53.3 & 4.4 & 830.0 & 226.5 & 0.1 & $43.7(153 / 350)$ & Mullin et al. (2010) \\
\hline & 35 & - & 35 & - & 10.0 & $0.5(1 / 198)$ & Chauzat et al. (2011) \\
\hline & 955 & - & 967 & - & NA & - & $\begin{array}{l}\text { DeGrandi-Hoffman } \\
\text { et al. (2013) }\end{array}$ \\
\hline & 302 & - & 310 & - & NA & - & $\begin{array}{l}\text { DeGrandi-Hoffman } \\
\text { et al. (2013) }\end{array}$ \\
\hline \multirow[t]{4}{*}{ Honey } & 46 & - & 80 & - & 4.0 & $41.9(13 / 31)$ & Pareja et al. (2011) \\
\hline & - & - & 15 & - & 0.8 & - & Rissato et al. (2007) \\
\hline & $\mathrm{ND}^{\mathrm{d}}$ & - & ND & - & 3.5 & $0(0 / 239)$ & Chauzat et al. (2011) \\
\hline & ND & ND & ND & - & 5.0 & $0(0 / 51)$ & $\begin{array}{l}\text { Choudhary and } \\
\text { Sharma (2008) }\end{array}$ \\
\hline
\end{tabular}

${ }^{\mathrm{a} B a s e d}$ on positive detections

${ }^{\mathrm{b} B a s e d}$ on calculations that included $0 \mu \mathrm{g} \mathrm{kg}^{-1}$ for non-detections

'Limit of detection

${ }^{\mathrm{d}} \mathrm{ND}=\mathrm{CPY}$ was included in residue analysis but was not detected

The mean concentration of CPY in almond pollen, collected from pollen traps on honey bee hives in an orchard in California that had been treated 2 wk earlier with Lorsban Advanced at $0.85 \mathrm{~kg} \mathrm{AI} \mathrm{ha}^{-1}$ (0.5 U.S. gal A ${ }^{-1}$ ) as a mixture with crop oil, was $955 \mu \mathrm{g} \mathrm{CPY} \mathrm{kg}{ }^{-1}$ wet weight (wwt) (DeGrandi-Hoffman et al. 2013). In contrast to the analyses conducted by Mullin et al. (2010), the QuEChERS multiresidue analytical method used by DeGrandi-Hoffman et al. (2013) used external calibration standards, which could not account for matrix effects. This method can give results with large "peak enhancement" errors that may exceed 20\% (Kwon et al. 2012). As a result, the concentrations reported can be considered as upper limit values but should be interpreted with caution. This value is $15 \%$ greater than the maximum concentration of CPY of $830 \mu \mathrm{g} \mathrm{kg}^{-1}$ and 3.7-fold greater than the 95th centile of $227 \mu \mathrm{g} \mathrm{kg}^{-1}$ (wwt) reported by Mullin et al. (2010). This study also characterized concentrations of CPY in other food components in the hive when the only pollen available to be bees contained residues of CPY. Mean concentrations of CPY in pollen used in the two experiments were 967 and $942 \mu_{\mathrm{g} \mathrm{kg}^{-1}}$ (wwt), and the corresponding concentrations in bee bread were 310 and $293 \mu \mathrm{g} \mathrm{kg}^{-1}$ (wwt), which suggests degradation had occurred (Table 2). No residues were detected in royal jelly or in queen larvae.

In a study examining in-hive concentrations of pesticides in various matrices collected from 24 apiaries in France, 2002-2005, CPY was detected only in one of 198 samples of trapped pollen (Chauzat et al. 2011) (Table 2). In western Uruguay, various honey bee hive matrices were collected from depopulated and healthy honey bee hives (Pareja et al. 2011). Approximately 4,800 samples were obtained from eight depopulated apiaries and approximately 10,000 hive samples were obtained from 29 healthy apiaries. Each set of samples was randomly sub-sampled. CPY was detected 
Table 3 Tier-2 estimates of chlorpyrifos (CPY) exposure through daily consumption of pollen and nectar by adult and larval honey bees

\begin{tabular}{|c|c|c|}
\hline $\begin{array}{l}\text { Life stage } \\
\text { (consumption } \mathrm{mg} \text { ) }\end{array}$ & Median dose $\left(\mu \mathrm{g} \text { CPY bee }{ }^{-1}\right)^{\mathrm{a}}$ & 95th centile dose $\left(\mu \mathrm{g} \text { CPY bee }{ }^{-1}\right)^{b}$ \\
\hline Adult (292) & $1.28 \times 10^{-3}$ & $6.61 \times 10^{-2}$ \\
\hline Larva (120) & $5.26 \times 10^{-4}$ & $2.72 \times 10^{-2}$ \\
\hline
\end{tabular}

${ }^{a}$ Based on median CPY detection in pollen of $4.4 \mu \mathrm{g} \mathrm{kg}^{-1}$ (Mullin et al. 2010)

${ }^{b}$ Based on 95th centile CPY detection in pollen of $226.6 \mu \mathrm{g} \mathrm{kg}^{-1}$ (Mullin et al. 2010)

in honey from just under half of analyzed samples, at a mean concentration similar to that found in pollen in the U.S. by Mullin et al. (2010) (Table 2). CPY was detected in honey in Brazil (Rissato et al. 2007) (Table 2), but the authors did not provide details on the frequency of detection. CPY was not among the many pesticides detected in honey collected from hives in France (Chauzat et al. 2011). Similarly, CPY was not detected in honey samples collected from beekeepers in India, although concentrations of organochlorine, cyclodiene, synthetic pyrethroids, and other organophosphorus insecticides were found (Choudhary and Sharma 2008) (Table 2).

The Tier-1 estimates of exposures of $110 \mathrm{mg} \mathrm{CPY} \mathrm{kg}^{-1}$ in nectar or pollen (per $1.12 \mathrm{~kg}^{-1} \mathrm{CPY} \mathrm{ha}{ }^{-1}$ ) appear to be overly conservative (protective). From the data reported by Mullin et al. (2010), CPY was not detected in most samples and, when detected, it was at concentrations several orders of magnitude below the modeled estimates from T-REX. Based on the data of Mullin et al. (2010) and the aggregate pollen and nectar (honey) consumption rates for larvae $\left(120 \mathrm{mg} \mathrm{d}^{-1}\right)$ and adult worker bees $\left(292 \mathrm{mg} \mathrm{d}^{-1}\right)$, the estimated dose of CPY received by honey bees would be several orders of magnitude below the Tier-1 modeled estimates of $110 \mathrm{mg}$ CPY $\mathrm{kg}^{-1}$ from T-REX (Table 3).

The above estimates of oral exposure were based on daily consumption rates of honey bees. There is greater uncertainty regarding rates of nectar and pollen consumption for non-Apis bees. However, an analysis of data recently compiled by EFSA (2012) suggests that adult honey bee workers and adult bumble bees have similar consumption rates, while that of adult female European mason bees and alfalfa leaf cutting bees is less. The same trends hold for larvae of these bees. Thus, exposures estimated from consumption of pollen and nectar by adult honey bees should be representative or protective of these non-Apis pollinators.

Estimates of post-application residual contact exposure on vegetation. Pollinators can come in contact with residues of CPY on flowers or inflorescences, or in some cases with extrafloral nectaries, following a spray application if flowers that were open during application remain attractive to pollinators after application. This is potentially a major route of exposure (Fig. 1). Residues on flowers are expected to be similar to or less than those found in or on foliage. These will be greatest immediately after spraying of foliage and thereafter dissipate rapidly through volatilization, photolysis, and dilution by growth of the plant. Residual contact exposure will also decline with time as visits of pollinators to older flowers decrease and visits to newer unsprayed flowers increase. This usually occurs within 1-3 d (Willmer 2011). 
Table 4 Dissipation and concentration of dislodgeable foliar residues following application of chlorpyrifos (CPY) to different plants

\begin{tabular}{|c|c|c|c|c|c|c|}
\hline Plant & $\begin{array}{l}\text { Application } \\
\text { rate }\left(\mathrm{kg} \mathrm{ha}^{-1}\right)\end{array}$ & $\begin{array}{l}\text { Half-life } \\
\text { (d) }\end{array}$ & $\begin{array}{l}\text { Time } \\
\text { (d) }\end{array}$ & $\begin{array}{l}\text { Residue } \\
\left(\mu \mathrm{g} \mathrm{cm}^{-2}\right)\end{array}$ & $\begin{array}{l}\text { Adjusted to } \\
1.12 \mathrm{~kg} \mathrm{ha}^{-1}\end{array}$ & Reference \\
\hline \multirow[t]{5}{*}{ Cotton } & \multirow[t]{5}{*}{1.12} & \multirow[t]{5}{*}{-} & 0 & 3.64 & 3.64 & \multirow{5}{*}{$\begin{array}{r}\text { Buck et al. } \\
\text { (1980) }\end{array}$} \\
\hline & & & 1 & 0.13 & 0.13 & \\
\hline & & & 2 & 0.071 & 0.071 & \\
\hline & & & 3 & 0.055 & 0.055 & \\
\hline & & & 4 & 0.034 & 0.034 & \\
\hline \multirow[t]{5}{*}{ Cotton } & \multirow[t]{5}{*}{1.12} & \multirow[t]{5}{*}{$<1$} & 0 & 3.62 & 3.62 & \multirow{5}{*}{$\begin{array}{r}\text { Ware et al. } \\
\quad(1980)\end{array}$} \\
\hline & & & 1 & 0.3 & 0.3 & \\
\hline & & & 2 & 0.191 & 0.191 & \\
\hline & & & 3 & 0.069 & 0.069 & \\
\hline & & & 4 & 0.068 & 0.068 & \\
\hline \multirow[t]{9}{*}{ Orange } & \multirow[t]{2}{*}{5.6} & \multirow[t]{2}{*}{-} & 4 & 0.013 & 0.003 & \multirow{9}{*}{$\begin{array}{r}\text { Iwata et al } \\
\text { (1983) }\end{array}$} \\
\hline & & & 10 & 0.005 & 0.001 & \\
\hline & \multirow[t]{3}{*}{11.21} & \multirow[t]{3}{*}{-} & 4 & 0.031 & 0.003 & \\
\hline & & & 10 & 0.012 & 0.001 & \\
\hline & & & 17 & 0.006 & 0.0006 & \\
\hline & \multirow[t]{4}{*}{11.21 (ULV) } & \multirow[t]{4}{*}{-} & 4 & 0.08 & 0.008 & \\
\hline & & & 10 & 0.021 & 0.002 & \\
\hline & & & 17 & 0.015 & 0.001 & \\
\hline & & & 31 & 0.008 & 0.0008 & \\
\hline \multirow[t]{2}{*}{ Grape fruit } & 5.6 & 2.4 & 3 & 0.035 & 0.007 & \\
\hline & 11.21 & 3.4 & 3 & 0.061 & 0.006 & \\
\hline \multirow[t]{3}{*}{ Cranberry } & \multirow{3}{*}{2.0} & \multirow[t]{3}{*}{3.8} & $0(2 \mathrm{~h})$ & 52.5 & 28.9 & \multirow{3}{*}{$\begin{array}{l}\text { Putnam } \\
\quad \text { et al. } \\
\text { (2003) }\end{array}$} \\
\hline & & & 3 & 23.95 & 13.2 & \\
\hline & & & 15 & 6.14 & 3.4 & \\
\hline \multirow[t]{5}{*}{$\begin{array}{l}\text { Kentucky } \\
\text { bluegrass }\end{array}$} & \multirow[t]{5}{*}{2.2} & \multirow[t]{5}{*}{$0.1-0.3$} & 0 & 0.14 & 0.07 & \multirow[t]{5}{*}{$\begin{array}{r}\text { Goh et al. } \\
\text { (1986) }\end{array}$} \\
\hline & & & 1 & 0.04 & 0.02 & \\
\hline & & & 2 & 0.03 & 0.015 & \\
\hline & & & 3 & 0.018 & 0.009 & \\
\hline & & & 4 & 0.013 & 0.007 & \\
\hline $\begin{array}{l}\text { Kentucky } \\
\text { bluegrass }\end{array}$ & 2 & $<1$ & & 0.456 & 0.251 & $\begin{array}{r}\text { Sears et al. } \\
(1987)\end{array}$ \\
\hline
\end{tabular}

An estimate of the upper-bound concentration of CPY likely to be on flowers can be obtained from the results of dislodgeable foliar residue studies (USEPA 2012). These studies show that CPY does not persist on plant surfaces. In some studies, dissipation was too rapid to produce meaningful dissipation curves (Iwata et al. 1983), but the average half-life was $1.5 \mathrm{~d}$ (Racke 1993; Solomon et al. 2001). The upper $90 \%$ confidence limit on the mean foliar half-life was $3.28 \mathrm{~d}$ (Williams et al. 2014). CPY that drifts onto non-target plants should dissipate at a similar rate, but initial concentrations would be less. Initial concentrations recorded for most crops were $<4 \mu \mathrm{g} \mathrm{cm}$, but were considerably larger for cranberry (Table 4 ). In a field 
study on cotton, the concentration of CPY declined to $3.6 \%$ of its initial value at $24 \mathrm{~h}$ and probably would not be efficacious for pest control (Buck et al. 1980). This suggests that exposure to pollinators would also be below toxic doses within a day after application. From reported values in Table 4, geometric means for concentrations of dislodgeable CPY at 0 and 3-4 d after spraying were 1.46 and $0.019 \mu \mathrm{g} \mathrm{cm}^{-2}$, respectively (adjusted for a $1.12 \mathrm{~kg} \mathrm{ha}^{-1}$ application rate).

Reported effects of irrigation on the concentration of dislodgeable residues on foliar surfaces have been variable (Table 4). Whereas immediate post-application irrigation did not affect the concentration of dislodgeable CPY from leaves of turf grass (Hurto and Prinster 1993), significant reductions in concentrations of CPY on grass foliage were found (4-fold difference after $6 \mathrm{~h}$ ) following post-spray irrigating with water, as recommended by the product label instructions for most turf insect control situations (Goh et al. 1986).

At least two studies have also examined dislodgeable concentrations of CPYO. After applications at $11.2 \mathrm{~kg} \mathrm{CPY} \mathrm{ha}{ }^{-1}$, no CYPO was detected with a detection limit of $0.01 \mu \mathrm{g} \mathrm{cm}^{-2}$. The results also showed very rapid disappearance of the parent insecticide (Iwata et al. 1983). On grapefruit leaves, trace amounts (0.013$0.028 \mu \mathrm{g} \mathrm{cm}^{-2}$ ) of CPYO were detected in samples collected $3 \mathrm{~d}$ after application. When applied to cranberry at $2 \mathrm{~kg} \mathrm{ha}^{-1}$, small amounts of CPYO were initially detected $\left(<7 \mu \mathrm{g} \mathrm{kg}^{-1}\right.$ ), but did not accumulate (Putnam et al. 2003). These results indicate that any CYPO formed on foliage is rapidly dissipated and does not accumulate. Given the demonstrated lack of potential exposure, higher Tier-refinement of the potential exposure to CPYO is not required.

\subsection{Other Potential Routes of Exposure}

Exposure via beeswax. Although wax is not consumed as food, there is direct contact between wax cell surfaces and food or individuals. Residues initially present in the wax could come from sublethal concentrations of CPY inside the body of bees that secrete the wax. After it is secreted, it may accumulate from contact with bees, pollen, nectar or other materials. The transfer of residues into or from wax is reversible and given the nonpolar nature of CPY it is likely that the partition of CPY between wax and bees or food substances tends toward equilibrium with higher concentrations in the wax. The net effect of absorption into wax is to reduce the potential for exposure of bees to CPY.

Several of the North American and European studies mentioned above examined concentrations of pesticides in beeswax collected from honey bee hives. Mullin et al. (2010) found CPY more often in foundation wax than in comb, but at similar concentrations (Table 5). Excluding pesticides that are used by beekeepers within hives to control Varroa mite parasites (fluvalinate, coumaphos, and its degradate coumaphos oxon), CPY was the most frequently detected pesticide in beeswax of the 118 pesticides and metabolites analyzed (Mullin et al. 2010). CPY was detected less often in beeswax collected from hives in France (Chauzat et al. 2011) and Spain 
Table 5 Concentrations of chlorpyrifos (CPY) detected in comb and foundation beeswax from honey bee colonies

\begin{tabular}{|c|c|c|c|c|c|c|c|}
\hline \multirow[b]{2}{*}{ Matrix } & \multicolumn{5}{|c|}{ Concentration $\left(\mu \mathrm{g} \mathrm{kg}^{-1}\right)$} & \multirow[b]{2}{*}{$\%$ of samples } & \multirow[b]{2}{*}{ Reference } \\
\hline & Mean $^{\mathrm{a}}$ & Median $^{\mathrm{b}}$ & Maximum $^{\mathrm{b}}$ & $\begin{array}{l}\text { 95th } \\
\text { centile }^{\mathrm{b}}\end{array}$ & $\mathrm{LOD}^{\mathrm{c}}$ & & \\
\hline \multirow[t]{5}{*}{$\begin{array}{l}\text { Comb } \\
\text { beeswax }\end{array}$} & 24.5 & 4.3 & 890.0 & 55.7 & 0.1 & $\begin{array}{l}63.2 \\
\quad(163 / 258)\end{array}$ & $\begin{array}{l}\text { Mullin et al. } \\
\text { (2010) }\end{array}$ \\
\hline & 14.9 & - & 19.0 & - & - & $3.5(3 / 87)$ & $\begin{array}{c}\text { Chauzat et al. } \\
\text { (2011) }\end{array}$ \\
\hline & 172 & - & - & - & 6.0 & $5.6(1 / 18)$ & $\begin{array}{l}\text { Serra-Bonvehí } \\
\text { and Orantes- } \\
\text { Bermejo } \\
(2010)\end{array}$ \\
\hline & 8 & - & 15 & - & 1.0 & $62(8 / 13)$ & Wu et al. (2011) \\
\hline & $\mathrm{ND}^{\mathrm{d}}$ & ND & ND & - & 1.0 & $0(0 / 31)$ & Cutler (2013) \\
\hline $\begin{array}{l}\text { Foundation } \\
\text { beeswax }\end{array}$ & 22.2 & 10.0 & 110.0 & 76.4 & 0.1 & $80.9(17 / 21)$ & $\begin{array}{l}\text { Mullin et al. } \\
\text { (2010) }\end{array}$ \\
\hline
\end{tabular}

${ }^{\mathrm{a}}$ Based on positive detections

${ }^{\mathrm{b}}$ Based on calculations that included $0 \mu \mathrm{g} \mathrm{kg}$ for non-detections 'Limit of detection

${ }^{\mathrm{d}} \mathrm{ND}=\mathrm{CPY}$ was included in residue analysis but was not detected

(Serra-Bonvehí and Orantes-Bermejo 2010) (Table 5). In 31 pooled samples of beeswax (samples from hives from a single site were pooled) collected from the Canadian provinces of Nova Scotia, Prince Edward Island, and New Brunswick, CPY was not detected (Cutler 2013).

In an assessment of effects on bees when exposed to pesticide-contaminated wax, samples of brood comb were taken from hives that were suspected to have died from Colony Collapse Disorder (Wu et al. 2011). Residue analyses were performed on brood comb samples. Of 13 frames of brood comb that contained large concentrations of pesticides, CPY was detected in approximately two-thirds of samples (Table 5).

Concentrations of CPY in beeswax reported by Mullin et al. (2010) were similar to those that were found in pollen and greater than those reported in bees or honey (Johnson et al. 2010; Mullin et al. 2010). Since wax is produced and exuded by bees in the hive, and concentrations are similar to those in pollen, it can be concluded that the concentrations in wax enter the hive mainly on pollen or as the sublethal body burden on forager bees. If wax is indeed a sink for CPY, the presence of CPY in beeswax may not result in exposure (see discussion in Sect. 2.3).

Exposures via soil. Many bees live in or utilize soil for construction of nests. For example, mason bees (Osmia spp.: Megachilidae) make compartments of mud in their nests, while mining bees (Andrenidae), digger bees (Anthophorinae), and sweat bees (Halictidae) are solitary underground nesters (Michener 2007). Pollinators that live in or use soil subject to application of pesticides can be exposed to CPY after application of either sprayable or granular formulations (Fig. 1). 
Although much has been written on communities of pollinators in agricultural landscapes and factors that influence diversity and abundance of bee populations in these habitats (Williams et al. 2010; Winfree et al. 2009), there is limited information on nesting habits of ground nesting bees within cropping systems (Julier and Roulston 2009; Kim et al. 2006; Williams et al. 2010; Wuellner 1999), and on exposure of ground nesting bees to pesticides. The potential use of data from surrogate species was therefore considered.

The exposure of arthropods to CPY in soil following application of spray or granular formulations on the soil surface has been studied, mainly for characterizing exposure in birds that consume insects (Moore et al. 2014; Solomon et al. 2001). Fewer studies have examined exposure of arthropods to CPY in soil, and these were done to evaluate the efficacy of CPY against pest insects (Clements and Bale 1988; Tashiro and Kuhr 1978; Tashiro 1987). None of these studies included pollinators. Exposures are different for ground-burrowing insect pests that ingest contaminated vegetation or soil, making these data unsuitable for estimating exposures of groundnesting pollinators. Thus, exposures of soil-dwelling pollinators via this route were not estimated and it remains an area of uncertainty.

Exposure via drinking-water. Water is potentially a significant route of exposure (Fig. 1). In obtaining water for a large number of individuals in a colony, honey bees collect much more water than other bees, and therefore serve as a conservative representative species for this route of exposure. Typical sources include wet foliage, puddles, soil saturated with water, or other sources where they can get access to water without drowning (Gary 1975; Winston 1987). Because CPY is not systemic, exposure to CPY through guttation water is not significant (Fig. 1).

Only a small proportion of the honey bees in a hive are dedicated to foraging for water and recruiting other bees to forage for water (Winston 1987). Water containing CPY brought back to the hive is limited to sublethal levels low enough that the ability of the forager to return to the hive is not affected. When demand for water is large, foraging can continue through the day. Individual loads of water average approximately $25 \mathrm{mg}$ although some loads can be larger, and each load can take approximately 10-12 min to obtain and deliver into the hive. If foraging continues for $10 \mathrm{~h}$, the forager would carry 50 loads or $1,250 \mathrm{mg}$ of water to the hive (Gary 1975) from a source such as a puddle. Honey bees do not forage during rain and the overlap of foraging time with the time when soil is wet enough for bees to collect soil pore water is short. Exposure from puddles is recommended to represent the worst case for collection of water from the soil surface (USEPA 2012).

The time when water can be obtained from wet foliage is also short. It takes approximately $1 \mathrm{~h}$ for wet foliage to dry. Foraging after the dew point is reached in the evening is unlikely, but more than one rain event is possible. If water is collected from wet foliage for $2 \mathrm{~h}$ each day the forager can carry as much as $250 \mathrm{mg}$ of water from that source. Temperature is lower and humidity is greater when the foliage is wet, and this reduces demand for water in the hive, making this an upper-limit estimate.

The amount of water a honey bee will actually drink is unknown (USEPA 2012) and likely variable. An estimated rate of intake of $47 \mu \mathrm{L} \mathrm{d}^{-1}$ based on direct 
measurements of water flux rates of the brown paper wasp (a similar species) is considered reliable by the USEPA for regulatory purposes (USEPA 2012). To simplify the risk assessment, it was assumed that bees collect their full daily requirement from the source with the highest concentration of CPY.

To estimate potential exposure of pollinators to CPY in water, it is also necessary to know or estimate the concentration of CPY in different water sources, which are expected to vary, and the amount of water pollinators derive from each potential source. The main potential sources are evaluated below:

Puddles and soil pore water. Several estimates of the concentration in puddles in the field are available. The USEPA recommends that concentrations of pesticides in puddles located on pesticide-treated fields be estimated using a modified version of the Tier-1 rice model (v. 1.0) (USEPA 2012). The model uses equilibrium partitioning to provide conservative estimates of environmental concentrations and assumes that puddles can be directly sprayed with pesticide and the pesticide will instantaneously partition between a water phase and a sediment phase, independent of the size of the puddle. With this model, the concentration is determined by partition equilibrium and does not increase as the puddle dries out; residues are deposited on the soil during drying to maintain the equilibrium. A sensitivity analysis was done to identify parameters that would give high-end estimates of exposure, and peak estimated concentrations are based on an application rate of $1.12 \mathrm{~kg} \mathrm{ha}^{-1}$. The model is represented in equation 1 (USEPA 2012).

$$
C_{w}=\frac{m_{C P Y}}{d_{w}+d_{\text {sed }}\left(\theta_{\text {sed }}+\rho_{b} k_{d}\right)}
$$

Where: $C_{w}$ is the concentration in water $\left(\mu \mathrm{g} \mathrm{L}^{-1}\right), m_{C P Y}$ is mass applied per unit area $\left(\mathrm{kg} \mathrm{ha}^{-1}\right), k_{d}$ is water-soil partition coefficient $\left(\mathrm{L} \mathrm{kg}^{-1}\right)$ (equivalent to $K_{O C} * 0.01$ ), $d_{\text {sed }}$ is sediment depth, $d w$ is water depth, $\rho_{b}$ is bulk density $\left(\mathrm{kg} \mathrm{m}^{-3}\right)$, and $\theta_{\text {sed }}$ is porosity.

Using the mean $K_{O C}$ value of 8216 for CPY (Solomon et al. 2014), the estimated concentration in puddle-water in a field following a spray application of $1.12 \mathrm{~kg}$ CPY ha ${ }^{-1}$ is $0.0051 \mu \mathrm{g} \mathrm{CPY} \mathrm{L}{ }^{-1}$. Assuming that the intake rate of water is $47 \mu \mathrm{L} \mathrm{d}^{-1}$ and that bees obtain $100 \%$ of their drinking water from such puddles on treated

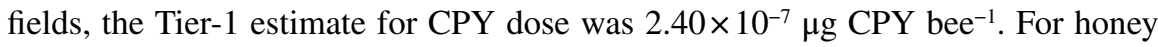
bees collecting $1,250 \mu \mathrm{L} \mathrm{d}^{-1}$ the estimated dose was $6.38 \times 10^{-6} \mu \mathrm{g}$ CPY bee ${ }^{-1} \mathrm{~d}^{-1}$.

The maximum concentration of CPY in puddles after application of both the granular formulations and the sprayable formulations was also modeled using PRZM/EXAMS, which provides both puddle and soil pore water concentrations (Williams et al. 2014). The maximum 95th centile of the peak pore water concentrations from the PRZM/EXAMS model among registered uses in the U.S. of the granular and the spray formulations were 571 and $566 \mu \mathrm{g} \mathrm{L}^{-1}$, respectively, based on a $1.12 \mathrm{~kg} \mathrm{CPY} \mathrm{ha}^{-1}$ application rate and the maximum number of applications per year. These values were obtained from the North Carolina tobacco and California broccoli standard use scenarios for PRZM/EXAMS, respectively (Williams et al. 2014). The greatest peak concentrations predicted for puddle water were $285 \mu \mathrm{g} \mathrm{L}^{-1}$ for 
granular and $529 \mu \mathrm{g} \mathrm{L}^{-1}$ for spray applications. Given the similarity of the pore water and puddle water values, only the highest value, $571 \mu \mathrm{g} \mathrm{L}^{-1}$ was selected for use in the risk assessment. With a daily intake of $47 \mu \mathrm{L}^{-1}$, the predicted 95 th centile of the maximum daily dose was $0.027 \mu \mathrm{g}$ bee $^{-1} \mathrm{~d}^{-1}$. The corresponding value for honey bees collecting $1,250 \mu \mathrm{L}$ of water $\mathrm{d}^{-1}$ for the hive is $0.71 \mu \mathrm{g}$ bee $^{-1} \mathrm{~d}^{-1}$. These estimates include peak values after storm events and are much greater than the equilibrium-based values in the Tier-1 Rice model. Exposure to these values is possible but depends on a combination of probabilities, limited to only a few use scenarios. In many use scenarios that were run in the PRZM/EXAMS model, the median predicted puddle concentrations were zero due to the large time interval between application and isolated heavy storm events during the 30 -yr simulation interval.

Dew and wet foliage. The USEPA recommends a conservative (protective) equilibrium partition model based on pesticide $K_{O C}$ and plant carbon content to estimate pesticide concentrations in dew (USEPA 2012) (Equation 2).

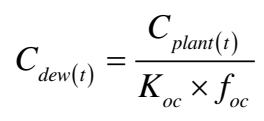

Where: $C_{\text {dew }(t)}$ is the concentration of dissolved pesticide in dew $\left(\mathrm{mg} \mathrm{L}^{-1}\right) ; C_{\text {plant }(t)}$ is the concentration of pesticide on and in plant leaves $\left(\mathrm{mg} \mathrm{kg}^{-1}\right.$ (fresh weight)) at

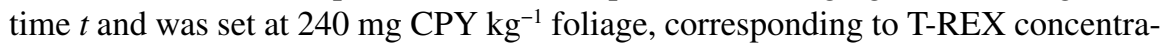
tions on short grass; and $f_{O C}$ is the fraction of organic carbon in leaves, set at 0.04 (4\% of fresh wt) based on estimates of carbon in plants (Donahue et al. 1983) and water content (Raven et al. 1992). As with the puddle model, this is an equilibrium equation and the concentration does not increase as the water dries on the surface. Partition into rainwater that remains on foliage after a rainfall is expected to be similar without runoff, or less if runoff occurs and reduces the amount of residue left on the leaf surface. Using the mean $K_{O C}$ of 8,216 (Solomon et al. 2014), $C_{\text {dew }(0)}$ for a spray application at $1.12 \mathrm{~kg} \mathrm{CPY} \mathrm{ha}^{-1}$ is $730 \mu \mathrm{g} \mathrm{L}^{-1}$. If a bee consumed $100 \%$ of its daily drinking water from contaminated dew and has an intake of $47 \mu \mathrm{L} \mathrm{d}^{-1}$, this model predicts a point estimate dose of $0.034 \mu \mathrm{g}$ CPY bee $\mathrm{d}^{-1}$. If the intake was $250 \mu \mathrm{L} \mathrm{d}^{-1}$, the dose would be $0.18 \mu \mathrm{g}$ CPY bee ${ }^{-1} \mathrm{~d}^{-1}$.

A second estimate of exposure for dew and/or wet foliage was obtained using the LiquiPARAM model, which gives both a mean and an estimate of variability (Moore et al. 2014). Using the same data as USEPA (2005), with the $K_{O C}$ for CPY and the $f_{O C}$ value of 0.40 derived for alfalfa, clover, bluegrass, corn stalk, and small grain straw this model predicts a worst-case mean CPY dew concentration (at 09:00 h, immediately after application) of $102 \mu \mathrm{g} \mathrm{CPY} \mathrm{L}{ }^{-1}$ and a 95th centile concentration of $210 \mu \mathrm{g} \mathrm{CPY} \mathrm{L} \mathrm{L}^{-1}$. If a bee consumed $100 \%$ of its daily drinking water from contaminated dew and has an intake $47 \mu \mathrm{L} \mathrm{d}^{-1}$, this model predicts mean and 95th centile daily doses of 0.0048 and $0.0099 \mu \mathrm{g}$ CPY bee ${ }^{-1}$, respectively. The corre-

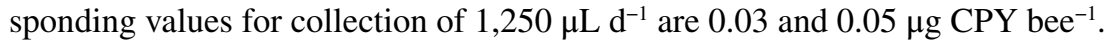

A variety of uses of CPY involve application by mixing the product in irrigation water or chemigation. These applications result in wet foliage with water that 
contains a high concentration of CPY and is available for extended intervals of time during the day. For example at the rate for peppermint, a $1 \mathrm{~cm} \mathrm{ha}^{-1}$ irrigation with an application at $2.12 \mathrm{~kg} \mathrm{ha}^{-1}\left(1.88 \mathrm{lb} \mathrm{A}^{-1}\right)$ would give a dose of over $600 \mathrm{ng} \mathrm{bee}^{-1}$ for a typical uptake of $30 \mu \mathrm{L}$ of water by a foraging bee in a single trip. This amount would be lethal, and foraging honey bees would not make it back to the hive to recruit more foragers to the wet foliage as a water source.

Other routes of exposure. Davis and Williams (1990) extended the typical approach of calculating intrinsic toxicity levels and field application rates to consider buffer zones downwind of sprayed areas and provide an estimates of the distance at which bees would encounter an $\mathrm{LD}_{50}$ dose from spray drift. These distances were determined using published data on spray depositions under various weather conditions for ground and aerial sprays of crops in Britain. They concluded that ground spraying of CPY at typical application rates would result in exposures of honey bees at the $\mathrm{LD}_{50}$ within $36-46 \mathrm{~m}$ of the application site at a wind speed of $4 \mathrm{~m} \mathrm{sec}-1$ $\left(14.4 \mathrm{~km} \mathrm{~h}^{-1}\right)$. Labels for products containing CPY state that sprays are not to be applied when wind speed exceeds $16 \mathrm{~km} \mathrm{~h}^{-1}$.

Only one reference on potential toxicity of CPY vapor to pollinators was found, indicating that vapor of Lorsban WP (50\% CPY) applied at $0.56 \mathrm{~kg}_{\text {product ha }}{ }^{-1}$ should not have effects on honey bees (Clinch 1972). There are no fumigant products based on CPY. While the lipophilicity of CPY $\left(\log K_{O W}=5.0\right)$ (Solomon et al. 2014) is high enough to make accumulation of CPY in honey bee wax from air plausible, the concentrations in air are very small and ephemeral. A maximum of $250 \mathrm{ng} \mathrm{m}^{-3}$ has been reported (Mackay et al. 2014). There is little evidence to support the possibility of accumulation of concentrations in wax in the hive from trace concentrations in the air.

\section{Toxicity of CPY to Pollinators}

\subsection{Tier-1 Tests of Effects}

Acute toxicity to A. mellifera. Acute toxicity of CPY to A. mellifera has been determined, and acute topical $\mathrm{LD}_{50}$ values ranged from $0.024 \mu \mathrm{g}$ bee $^{-1}$ to $0.55 \mu \mathrm{g}$ bee $^{-1}$ (Table 6). A. mellifera appears to be slightly less sensitive to CPY by the dietary route, with oral $\mathrm{LD}_{50}$ values ranging from $0.114 \mu \mathrm{g}^{-1}$ with technical product, to $2.15 \mu \mathrm{g} \mathrm{bee}^{-1}$ of formulated product $(18.7 \% \mathrm{CPY}$ ) (Table 7$)$.

One study was found that reported the acute toxicity of CPY to honey bee larvae. Atkins and Kellum (1986) carried out studies to determine the potential hazard to honey bee brood of pesticide contaminated food in the hive. Pesticides were added to individual brood cells followed by monitoring of effects throughout the brood cycle and into the adult stage. This resulted in a combined oral and cuticular exposure. For CPY (Lorsban 4E), 5-6 day-old larvae were the most susceptible age-group, whereas 1-2 day-old larvae were the least susceptible. The recorded $\mathrm{LD}_{50}$ values for 
Table 6 Acute topical toxicity ( $48 \mathrm{~h}$ unless indicated otherwise) of technical and formulated chlorpyrifos (CPY) to the honey bee

\begin{tabular}{|c|c|c|c|}
\hline Formulation & $\%$ Purity & 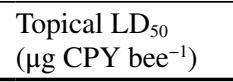 & Reference \\
\hline Technical & $\geq 95$ & $0.059^{\mathrm{a}}$ & Stevenson (1978) \\
\hline Technical & $99 \%$ & $0.115^{\mathrm{b}}$ & Mansour and Al-Jalili (1985) \\
\hline $\begin{array}{l}\text { Technical product } \\
\text { geometric mean }\end{array}$ & & 0.082 & \\
\hline Lorsban 48E & 48 & 0.024 & Carrasco-Letelier et al. (2012) \\
\hline Dursban F & 97.4 & 0.070 & Chen (1994) \\
\hline Lorsban Advanced & 41.1 & $0.14^{\mathrm{c}}$ & Schmitzer (2008) \\
\hline Dursban 480 & 48 & 0.22 & Bell (1993) \\
\hline Dursban WG & 75 & 0.54 & Bell (1996) \\
\hline $\begin{array}{l}\text { Formulated product } \\
\text { geometric mean }\end{array}$ & & 0.123 & \\
\hline \multicolumn{4}{|c|}{$\begin{array}{l}\text { aTest duration not reported } \\
\text { b } 25 \text { h test duration } \\
{ }^{2} \text { Reported as } 0.35 \mu \mathrm{g} \text { product bee }{ }^{-1} \text {, formulation code GF- } 2153\end{array}$} \\
\hline \multicolumn{4}{|c|}{$\begin{array}{l}\text { Table } 7 \text { Acute oral toxicity ( } 48 \mathrm{~h} \text { unless indicated otherwise) of technical and formulated } \\
\text { chlorpyrifos (CPY) to the honey bee }\end{array}$} \\
\hline Formulation & $\%$ Purity & $\begin{array}{l}\text { Oral } \mathrm{LD}_{50} \\
\left(\mu \mathrm{g} \mathrm{CPY} \text { bee }^{-1}\right)\end{array}$ & Reference \\
\hline Technical & $\geq 95 \%$ & $0.114^{\mathrm{a}}$ & Stevenson (1978) \\
\hline Lorsban 4E & - & $0.11^{\mathrm{b}}$ & Atkins and Kellum (1986) \\
\hline Dursban 4 & 48 & 0.29 & Anonymous (1986) \\
\hline Dursban 480 & 48 & 0.33 & Bell (1993) \\
\hline Dursban F & 97.4 & 0.36 & Chen (1994) \\
\hline Lorsban Advanced & 41.1 & $0.39^{\mathrm{c}}$ & Schmitzer (2008) \\
\hline Lorsban $50 \mathrm{WP}$ & 50 & $0.4^{\mathrm{b}}$ & Clinch (1972) \\
\hline Lorsban $50 \mathrm{~W}$ & 50.2 & $0.46^{\mathrm{d}}$ & Hahne (2000) \\
\hline Dursban WG & 75 & 1.1 & Bell (1996) \\
\hline $\begin{array}{l}\text { Formulated product } \\
\text { geometric mean }\end{array}$ & & 0.36 & \\
\hline
\end{tabular}

Test duration not reported

${ }^{\mathrm{b}} 24 \mathrm{~h}$ test duration

'Reported as $0.94 \mu \mathrm{g}$ product bee ${ }^{-1}$, formulation code GF-2153

${ }^{\mathrm{d}}$ Reported as $0.91 \mu \mathrm{g}$ product bee ${ }^{-1}$

1-2, 3-4, and 5-6 day-old larvae and adults were 0.209, 0.302, 0.066, and $0.11 \mu \mathrm{g}$ bee $^{-1}$, respectively (Atkins and Kellum 1986). Based on these data, the $\mathrm{LD}_{50}$ geometric mean for all larval stages was $0.146 \mu \mathrm{g} \mathrm{CPY}$ larvae $^{-1}$ (the authors report a mean of $0.051 \mu \mathrm{g}$ larvae ${ }^{-1}$, although it is unclear how this value was derived), which is approximately twice the topical $\mathrm{LD}_{50}$ for adult bees. Therefore, $\mathrm{LD}_{50}$ values for adult bees are protective of the larval life stages.

Effects on non-target arthropods (NTA) as a surrogate for non-Apis bees. It has been recommended that Tier-1data for NTA be generated by exposing Aphidius 
rhopalosiphi and Aphidius pyri to fresh dried residues of product applied on glass plates to generate $\mathrm{LR}_{50}$ values (rate of application of the pesticide causing 50\% mortality of the test organisms) (Candolfi et al. 2001). This test is meant to represent a case worse than that experienced on a natural substrate such as a leaf. No reports of toxicity data for CPY to A. rhopalosiphi and T. pyri using the glass plate technique were found, but data for Bracon hebetor (Braconidae) and A. ervi, which are related species of wasps were found. The $\mathrm{LR}_{50}$ value for $B$. hebetor was $62 \mathrm{~g}$ CPY $\mathrm{ha}^{-1}$ (Ahmed and Ahmad 2006) and that for adult female A. ervi was $0.047 \mathrm{~g}$ CPY $\mathrm{ha}^{-1}$ (Desneux et al. 2004). These results were obtained with the active ingredient coated on the inside of a $2.3 \mathrm{~cm}$ diameter by $9.3 \mathrm{~cm}$ glass vial in which the wasp was contained, leading to a greater potential uptake of the dose from the surface than would occur under field conditions. Thus, the results may be useful for comparison of toxicity but are not an indication of toxicity in the field. At present, too few data obtained using this method are available to permit comparisons to be made among species. In addition, the small size (and large surface area to volume ratio) of these wasps suggests that they may experience greater exposures via contact with treated surfaces than the larger pollinators and thus would be poor surrogates.

\subsection{Tier-2 Tests of Effects}

Semi-field studies. The following semi-field (tunnel tests) studies were conducted in Europe and with formulations not currently registered in the U.S. Nonetheless, these studies were conducted using standard methods with formulations containing amounts of active ingredient similar to that in current US formulations and therefore provide data that are relevant in the assessment of risk of CPY to pollinators.

A semi-field experiment with mini-beehives (approximately 2,000 individuals) in field cages large enough to allow foraging behavior to be assessed in a contained colony was conducted to test effects of exposure of honey bees to CPY and other pesticides at a series of times after application (Bakker and Calis 2003). When potted Phacelia plants treated with Dursban 75WG (76.3\% CPY) at $1 \mathrm{~kg} \mathrm{CPY} \mathrm{ha}^{-1}$ were added to the cages at night, the number of dead bees collected outside hives was significantly greater compared to control hives on the first day of exposure, but not on subsequent days. Foraging activity of bees was also reduced for up to $4 \mathrm{~d}$ following the exposure phase (Bakker and Calis 2003).

In another tunnel test, the effects of aged Dursban 75WG foliar residues on behavior and mortality of foragers, and brood development of A. mellifera was examined (Bakker 2000). Dursban 75WG was applied at $1 \mathrm{~kg} \mathrm{CPY} \mathrm{ha}^{-1}$ to potted Phacelia tanacetifolia under outdoor conditions at 14, 7, 5, and $3 \mathrm{~d}$ before exposure, and the evening before exposure. During the aging process, plants were placed under UV-transparent synthetic foil to protect them from rain. Exposure to aged CPY did not result in a statistically significant increase in the number of dead bees. However, reduced foraging activity was observed in all treatments. Exposure to 1 or $3 \mathrm{~d}$-old CPY residues resulted in an immediate reduction of foraging activity that 
Table 8 Vitality of bumble bee, B. impatiens, colonies following 2-wk exposure to dry chlorpyrifos (CPY) on mixed stands of turf and flowering white clover (adapted from Gels et al. 2002)

\begin{tabular}{lcc}
\hline Colony measure & Control & CPY \\
\hline Weight $(\mathrm{g})$ & & \\
Colony (without hive) & $193.4 \pm 26.3$ & $107.8 \pm 7.2^{\mathrm{a}}$ \\
Workers & $23.1 \pm 4.9$ & $7.5 \pm 1.1^{\mathrm{a}}$ \\
Queen & $0.78 \pm 0.05$ & $0.78 \pm 0.08$ \\
No. in colony & & \\
Workers & $132.8 \pm 19.6$ & $56.8 \pm 6.5^{\mathrm{a}}$ \\
Honey pots & $41.8 \pm 12.9$ & $5.5 \pm 3.6^{\mathrm{a}}$ \\
Brood chambers & $56.0 \pm 5.1$ & $3.5 \pm 1.3^{\mathrm{a}}$ \\
\hline
\end{tabular}

${ }^{a}$ Indicates statistically significant $(\alpha=0.05)$ based on analysis with four treatments: control, CPY, carbaryl (not shown) and cyfluthrin (not shown)

lasted the duration of the 4-d post-exposure assessment period. Exposure to older residues of Dursban resulted in a delayed reduction in forager activity. Since the effect persisted longer than in any other study, there could have been a repellent effect from a component of the formulation other than the active ingredient, or the memory by bees of CPY on foliage might have been a retained behavioral influence on foraging, possibly involving the level of demand for food in the hives. No effects on brood development were seen in any treatment (Bakker 2000).

In conditions such as those presented in these studies, where bees are confined to experimental plots with a lack of choice of forage, it appears that CPY is toxic for the first $24 \mathrm{~h}$ post-application but only has sublethal effects such as repellency after $24 \mathrm{~h}$. Repellency is considered a sublethal effect but it may be beneficial and is only an indirect adverse effect in that it may result in a reduced food supply to the hive. Avoidance of a pollinator to potentially harmful CPY residues is beneficial.

Toxicity studies with non-Apis pollinators. Acute toxicity data for pesticides and non-Apis pollinators is far less common than for A. mellifera. No reports of contact and oral $\mathrm{LD}_{50}$ values for $\mathrm{CPY}$ to Bombus spp. were found. However, a semi-field study with B. impatiens Cresson was conducted (Gels et al. 2002). Colonies of B. impatiens confined in field cages were exposed to dried residues of CPY on weedy turf $24 \mathrm{~h}$ after application of Dursban $50 \mathrm{~W}$ at $1.12 \mathrm{~kg} \mathrm{CPY} \mathrm{ha}^{-1}$. Effects on colonies were evaluated at $14 \mathrm{~d}$. Adverse effects on vitality of bumble bee colonies were observed, including fewer worker bees, honey pots (stored food), and brood chambers in hives from treated plots relative to control plots (Table 8). Biomass of workers and weights of colonies were also reduced, and two of the four colonies had no live brood or adults. Reduced foraging activity was also recorded when bumble bee colonies were confined to CPY-treated plots, although endemic bumble bees did not avoid foraging on CPY-treated flowering white clover intermixed with turf (Gels et al. 2002).

Some species of non-Apis bees can be exposed to residues of CPY on nesting materials such as foliage or soil collected in or near treated crops. Adults can be 
exposed when collecting these materials and building nest cells, and immature stages developing in these cells may also be exposed. When caged adult alfalfa leafcutting bees, $M$. rotundata, were exposed to alfalfa plants sprayed with CPY (Lorsban 4E, $2.5 \mathrm{~kg} \mathrm{ha}^{-1}$ ), significant mortality was observed. The population of males was reduced by approximately $90 \%$ after only $2 \mathrm{~d}$, and the population of females was reduced by $30 \%$ relative to the controls. No significant additional mortality of female $M$. rotundata was observed after the first 4-5 d of exposure (Gregory et al. 1992). It was suggested that male $M$. rotundata were more sensitive to CPY due to their reduced metabolic capacity and smaller surface area to volume ratio compared to females.

Studies to evaluate the toxicity of CPY to three species of bees have been conducted (Lunden et al. 1986). Field applications of $1.12 \mathrm{~kg} \mathrm{ha}^{-1}$, followed by 24-h continuous exposure to the treated foliage in small cages was lethally toxic to adult honey bees, alfalfa leafcutting bees ( $M$. rotundata), and alkali bees (Nomia melanderia Cock.) for 5-7 d, whereas a rate of $0.56 \mathrm{~kg} \mathrm{ha}^{-1}$ was toxic for 4-6 d. In field tests on several crops, mortality was observed with application of CPY and reduced foraging was observed for 1-7 d (Lunden et al. 1986).

Effects on NTA as a surrogate for non-Apis bees. Tier-2 tests with surrogate NTA species on a natural substrate such as foliage are more realistic than Tier-1 tests that utilize glass plates (Candolfi et al. 2001), but are still conservative because the test organisms are constrained on or near the treated surface. As with the Tier-1 assessment, no contact toxicity data were found for the recommended wasp species A. rhopalosiphi. There were data for B. hebetor (Ahmed and Ahmad 2006) exposed to CPY via leaves of cotton, but unfortunately the method of treatment, dipping the leaves in an aqueous solution, did not allow the deposition on the surface of the leaf to be calculated, making the data unusable in this risk assessment.

\subsection{Tier-3 Field Tests}

Several field studies have been conducted to examine the effects on honey bees of applications of CYP to agricultural crops. These effects are summarized in Table 9 and are described in more detail below. The applications made in these field studies did not follow current label restrictions, which prohibit application when bees are actively foraging. The results from application during bloom in a number of crops under various exposure scenarios suggests that CPY remains lethal to honey bees for 1-2 d after application on open flowers and may reduce foraging for several days thereafter.

Dursban was sprayed by helicopter on unreplicated 16-A (approx. $6.5 \mathrm{ha}$ ) blooming alfalfa fields that contained 1-3 honey bee colonies $A^{-1}$ (Atkins et al. 1973). When applied at night at the highest rate of $1.12 \mathrm{~kg} \mathrm{ha}^{-1}$, Dursban killed an average of 365 bees per colony for $1 \mathrm{~d}$ and depressed bee visitation for approximately $3 \mathrm{~d}$. Because honeybee colonies typically contain 30-60 thousand bees in midsummer when 


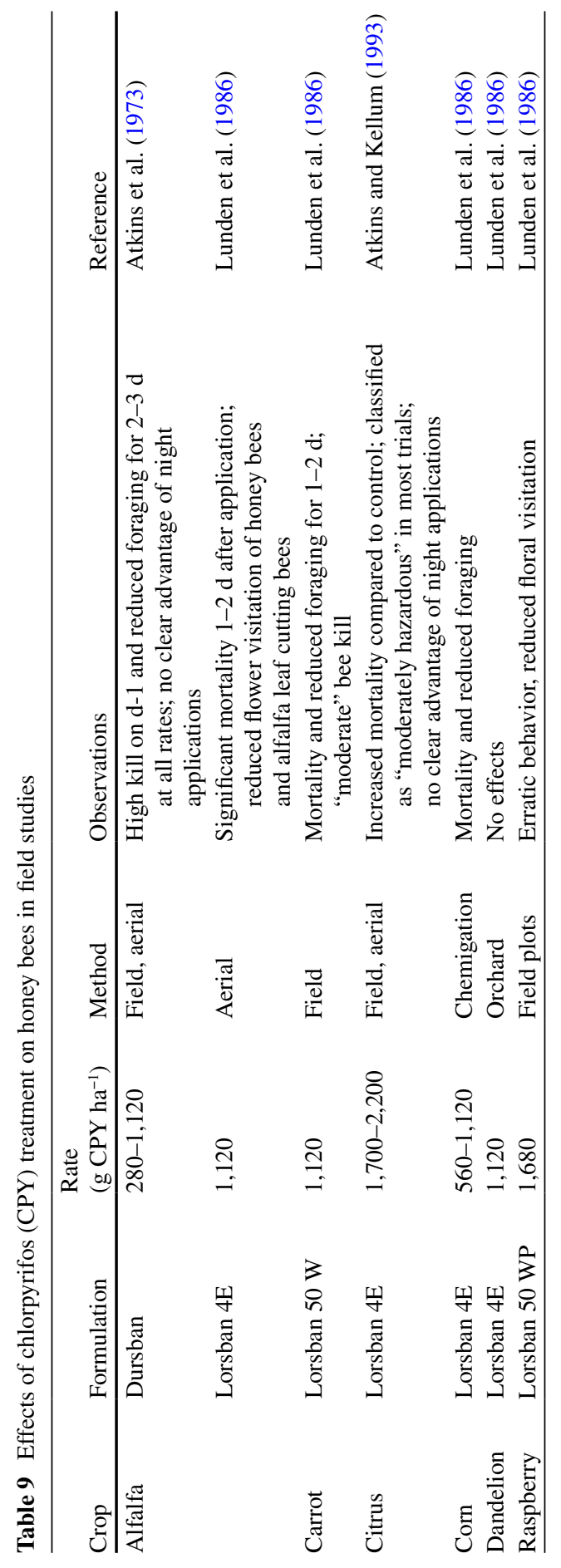


alfalfa is in bloom, the loss of this many bees is not likely to be significant for the health of the colony. It is unclear whether reduced visitation was due to mortality of bees, a repellent effect of the treated foliage, or, if the lack of bees returning to the hive to communicate the location of the food resource in the treated area lead to a shift in foraging to areas from which bees did return. Laboratory bioassays with this field-treated foliage killed $100 \%$ of exposed bees for $3 \mathrm{~d}$. Unfortunately the concentration of CPY per unit of surface area was not determined. Results were similar but less severe at lesser concentrations of Dursban. No dead bees were found at the colonies when Dursban was applied at $0.28 \mathrm{~kg} \mathrm{ha}^{-1}$ in the morning, although visitations on the field were moderately depressed for $2 \mathrm{~d}$. Bioassays of foliage aged for $12 \mathrm{~h}$ from this treatment killed $100 \%$ of bees, and showed $0-31 \%$ kill on foliage aged 48-96 h (Atkins et al. 1973).

A number of field trials examining mortality and visitation to flowers in alfalfa, raspberry, dandelion, carrot, and corn were reported by Lunden et al. (1986). In field tests on alfalfa in Washington State, Lorsban 4E was applied by aircraft at $1.12 \mathrm{~kg}$ CPY ha ${ }^{-1}$ to several 0.4-0.8 ha plots in the evening (19:00-21:00 h). Each location contained two honey bee colonies and three nesting boards with alfalfa leafcutting bees adjacent to the crop. Mortality of honey bees in the treated plots was five-to eight-fold higher than in controls. A 56-67\% reduction in nesting along with reductions in visits to flowers of up to $100 \%$ was reported for alfalfa leafcutting bees. The authors concluded that "low-range" honey bee kills occurred (100-200 dead bees per day on an apron in front of a hive), but colonies did not die. Leafcutting bees, which do not have multiple generations per year, would suffer more. It was also suggested that application of CPY to blooming alfalfa would seriously reduce seed set in crops grown for seed. Lorsban $4 \mathrm{E}$ applied to single 0.004 ha plots of dandelions in pear and apple orchards at $1.12 \mathrm{~kg} \mathrm{CPY} \mathrm{ha}^{-1}$ caused no reductions in the number of honey bees foraging and no effects on behavior (Lunden et al. 1986).

When Lorsban 50 WP (1.68 $\left.\mathrm{kg} \mathrm{CPY} \mathrm{ha}^{-1}\right)$ was applied by ground-sprayer to raspberry plots in the evening (Lunden et al. 1986), bees behaved erratically after foraging on blossoms $1 \mathrm{~d}$ after treatment, in that they would "mill around, land on leaves and walk in a wobbly fashion". Visitation to flowers was $40 \%$ of that observed in the control on $\mathrm{d}-1$ and remained reduced for $7 \mathrm{~d}$. Bioassays conducted in cages with 3-d-old foliage resulted in $70 \%$ mortality of honey bees after $24 \mathrm{~h}$. Chlorpyrifos is no longer registered for use on raspberries.

Lorsban $50 \mathrm{~W}$ applied to a single, blooming carrot field (8.1 ha) at $1.12 \mathrm{~kg}$ CPY $\mathrm{ha}^{-1}$ containing adjacent honey bee hives resulted in over 12 -fold more dead bees and reduced foraging on the crop the day after application, and threefold more dead bees $2 \mathrm{~d}$ after application. The actual number of bees lost was considered to be only a moderate honey bee kill (250-500 dead bees per hive from an Apron type dead bee trap or 500-950 from a Todd type dead bee trap) based on criteria of Mayer and Johansen (1983), and the long-term viability of the hive was not affected (Lunden et al. 1986). In an unreplicated corn field with adjacent honey bee hives, application of CPY resulted in four-fold more dead bees and 95\% reduced foraging on corn pollen compared to pre-application counts (Lunden et al. 1986). It is unclear whether there was an overall reduction in foraging, or whether bees simply avoided the CPYtreated plots. Impacts on long-term survival of the hives were not reported. 
Several field trials have been done to assess effects of CPY on citrus on honey bees (Atkins and Kellum 1993). Lorsban 4E was sprayed on unreplicated blooming $1.2 \mathrm{~A}$ citrus plots at $2.2 \mathrm{~kg} \mathrm{ha}^{-1}$ in the morning or in the evening. Colonies in plots treated with Lorsban in the morning had "moderate to light" mortality (274 dead bees over $4 \mathrm{~d}$ ), with $33 \%$ fewer dead bees than colonies in plots treated in the evening (395 dead bees over $4 \mathrm{~d}$ ), which was classified as "moderately hazardous". This rate of bee deaths is not expected to affect the long-term colony survival and the authors concluded that Lorsban could be applied to citrus as an evening or early morning treatment without causing serious honey bee kills.

In a second trial in citrus, honey bee colonies were placed in 10-A plots of blooming citrus and sprayed in the evening with Lorsban 4E at $1.7 \mathrm{~kg} \mathrm{ha}^{-1}$ (Atkins and Kellum 1993). Treatment suppressed visitation by $64 \%$ for approximately $2 \mathrm{~d}$ and killed an average of 904 bees colony $^{-1}$ over $1.5 \mathrm{~d}$, suggesting a moderate to high overall hazard, based on the expert opinion of the authors. In another trial, unreplicated 2-A ( $0.81 \mathrm{ha})$ plots of citrus in full bloom were aerially treated with Lorsban at $1.7 \mathrm{~kg} \mathrm{ha}^{-1}$ in the morning or evening using a helicopter. In contrast to what might be predicted, the night treatment of CPY was moderately hazardous to bees, whereas the morning application of CPY was rated as having a low hazard (Atkins and Kellum 1993).

Despite short-term lethal effects on honey bees, colonies should be able to survive such exposure with few long-term effects. The risk is reduced or eliminated if application is not made when flowers are open, since CPY is not systemic and is not translocated to newly opened flowers. Non-Apis pollinators with females that annually establish nests that are much smaller than that of the honey bee, are likely to be more sensitive to CPY exposure.

\subsection{Other Studies on the Effects of CPY}

Toxicity from exposures via beeswax. The potential effect of exposure to CPY contaminated beeswax on honey bees has not been studied extensively. One study reported concentrations of 39 pesticides found in frames of brood comb from hives from the Pacific Northwest, and from colonies provided by the USDA-ARS honey bee laboratory that were suspected to have died from Colony Collapse Disorder (Wu et al. 2011). Worker bees were reared in brood comb containing concentrations of known pesticides that were considered to be high, and in relatively uncontaminated brood comb used as the control. CPY was detected in some comb samples, but no effects were reported where CPY was present (Wu et al. 2011).

Effects on virus titres. In a study with bee colonies placed in field cages large enough to allow foraging in a controlled area but still contain the bees, the frequency of occurrence and titer of viruses in nurse bees, royal jelly, and various life stages of queen bees reared in colonies fed only almond pollen from trees previously treated 
Table 10 Concentrations of chlorpyrifos (CPY) detected in honey bees

\begin{tabular}{|c|c|c|c|c|c|c|}
\hline \multicolumn{5}{|c|}{ Concentration $\left(\mu \mathrm{g} \mathrm{kg}^{-1}\right)$} & \multirow[b]{2}{*}{$\%$ of samples } & \multirow[b]{2}{*}{ Reference } \\
\hline Mean $^{\mathrm{a}}$ & Median $^{\mathrm{b}}$ & Maximum $^{\text {b }}$ & $\begin{array}{l}95 \text { th } \\
\text { centile }^{\mathrm{b}}\end{array}$ & $\mathrm{LOD}^{\mathrm{c}}$ & & \\
\hline 3.4 & 2.2 & 10.7 & 9.7 & 0.1 & $8.6(12 / 140)$ & Mullin et al. (2010) \\
\hline $\mathrm{ND}^{\mathrm{d}}$ & - & ND & - & 10.0 & $0(0 / 307)$ & Chauzat et al. (2011) \\
\hline 43 & - & 57 & - & $30.0^{\mathrm{e}}$ & $3.2(3 / 92)$ & Ghini et al. (2004) \\
\hline 77 & - & 80.6 & NA & NA & NA & $\begin{array}{c}\text { DeGrandi-Hoffman } \\
\text { et al. (2013) }\end{array}$ \\
\hline
\end{tabular}

${ }^{\mathrm{a}}$ Based on positive detections

${ }^{\mathrm{b}}$ Based on calculations that included $0 \mu \mathrm{g} \mathrm{kg} \mathrm{k}^{-1}$ for non-detections 'Limit of detection

${ }^{\mathrm{d}} \mathrm{ND}=\mathrm{CPY}$ was included in residue analysis but was not detected eLimit of quantification

with $955 \mu \mathrm{g}$ CPY kg-1 was compared to that in colonies with free access to flora of the southwestern US desert (DeGrandi-Hoffman et al. 2013). The experiment was repeated using the same pollen to which Pristine ${ }^{\circledR}$ (boscalid + pyraclostrobin) fungicide was added. The authors reported that deformed wing virus (DWV) was not detected in emerged queens grafted from or reared in the reference colonies but was found in all emerged queens grafted from or reared in colonies where pollen contained CPY (DeGrandi-Hoffman et al. 2013). Titres of DWV in queen larvae and emerged queens were less than two-fold those in nurse bees in some treatments.

This study had a number of weaknesses. Treatments were not matched to appropriate controls. Bees exposed to CPY were restricted to almond pollen alone with no reserves of other pollen in the hive. Pollen from almond trees might not have been nutritionally sufficient (Somerville 2005) and contains the natural toxin amygdalin at concentrations that are sublethal for honey bees (Somerville 2005). In contrast, control bees were free to forage on plants of the southwestern desert, which are known to provide the complete nutritional requirement for bees (Ayers and Harman 1992); the correct control should have been almond pollen without CPY. Thus, potential nutritional effects from different pollen sources were confounded with the potential effects of CPY and the applied fungicides. It was not clear whether the uncaged, reference colonies had reserves of pollen or bee bread. Also, there was no evidence of exposure of the queens. CPY was not detected in royal jelly or in queens so exposures, if any, were less the limit of detection $\left(0.1 \mu \mathrm{g} \mathrm{kg}^{-1} \mathrm{wwt}\right)$ and much less than a toxic dose (Table 7). CPY was detected in nurse bees but no symptoms of toxicity were described and they had lower titres of virus, which is the opposite of what would be expected if there were a relationship between CPY exposure and titer of virus. Another weakness of the study was exposure to only one concentration of CPY, which precluded the characterization of a concentrationresponse, a key factor in the determination of causality.

Concentrations of CPY found in honey bees. Pollinators can be exposed to CPY by contact with spray droplets or residues on surfaces such as pollen, foliage or blossoms. The extent of transfer of these residues to pollinators can be estimated from published residue data for CPY in bees (Table 10). CPY was detected in a small 
Table 11 Reported chlorpyrifos (CPY) incidents with honey bees in the U.S., 1990-present (USEPA 2013)

\begin{tabular}{lclll}
\hline & \multicolumn{5}{l}{ Reported CPY Incidents with Honey Bees } \\
\cline { 2 - 5 } Crop & $1990-1999$ & $2000-2009$ & 2010 -present & No date Specified \\
\hline Agricultural area & 4 & 0 & 0 & 2 \\
$\quad$ (not specified) & & 1 & 0 & \\
Alfalfa & 1 & 0 & 0 & \\
Apple & 1 & 0 & 0 & \\
Bean & 1 & 0 & 0 & \\
Carrot & 2 & 0 & 0 & \\
Carrot seed & 1 & 0 & 0 & \\
Cherry & 0 & 1 & 0 & \\
Corn & 0 & 0 & 1 & \\
Cotton & 0 & 0 & 0 & \\
Orchard & 4 & 0 & 0 & \\
Orchard (unspecified) & 5 & 1 & 0 & \\
Soybean & 0 & 1 & 0 & \\
Not reported & 7 & 4 & 1 & \\
TOTALS & 26 & &
\end{tabular}

portion of bee samples collected from hives throughout the U.S., at concentrations up to $10.7 \mu \mathrm{g}$ CPY $\mathrm{kg}^{-1}$. Samples consisted of live adult nurse bees removed from brood nests (Mullin et al. 2010). Live worker bees were collected several times during the season from hives in France, but CPY was not detected in any samples (Chauzat et al. 2011). In Italy, CPY in bees was detected in only a small portion of samples (Ghini et al. 2004) (Table 10). Thus, detection of CPY in honey bees collected in the field was infrequent. Assuming an adult worker honey bee weighs $93 \mathrm{mg}$ (Winston 1987), a honey bee worker is estimated to contain up to $9 \times 10^{-4} \mu \mathrm{g}$ CPY, based on the 95th centile estimate of $9.7 \mu \mathrm{g} \mathrm{CPY} \mathrm{kg}{ }^{-1}$ reported by Mullin et al. (2010). The median concentration of $2.2 \mu \mathrm{g} \mathrm{CPY} \mathrm{^{-1 }}$ reported by Mullin et al. (2010) provides an estimate of $2 \times 10^{-4} \mu \mathrm{g}$ CPY bee ${ }^{-1}$.

In an experiment where nucleus colonies (five frames with 3000 adults, a queen, larvae) of honey bees were held in cages and fed almond pollen from trees previously sprayed with CPY, or CPY and boscalid + pyraclostrobin, concentrations in bodies of nurse bees were 80.6 and $72.7 \mu \mathrm{g} \mathrm{CPY} \mathrm{kg}{ }^{-1}$ (wwt), respectively (DeGrandi-Hoffman et al. 2013). Because bees were held in cages and only had access to trays of pollen from almond trees intentionally treated with CPY, it is not surprising that these values are higher than concentrations reported from field monitoring surveys (Table 10).

Incident Reports. Considering the widespread use of CPY in agriculture in the U.S., data obtained from the USEPA Office of Pesticide Programs show that the number of honey bee incidents reported is very low, and has decreased over the past two decades (USEPA 2013). Reported incidents range from those involving a few to hundreds of honey bee colonies, and involve exposure following registered uses and misuse of CPY. As well, the level of certainty as to whether or not CPY caused the reported incidents was variable, ranging from "unlikely" to "highly probable". The reported incidents since 1990 are listed in Table 11. 
Incident report data were also obtained from the Pest Management Regulatory Agency (PMRA) of Health Canada. Since 2007, when reporting of honey bee pesticide incidents was officially initiated, there have been only nine reports potentially implicating CPY as the cause of the incident. All reports were from the province of Saskatchewan in 2012. Four of these incidents were classified as "minor" by PMRA ( $\leq 10 \%$ of bees suffering lethal or sublethal effects), three were classified as "moderate" (10-30\% of bee affected), and two incidents were classified as "major" ( $\leq 30 \%$ affected).

\section{Characterization of Risk of CPY to Pollinators}

Hazards and risks were calculated using the margin of exposure method to generate RQ values. For CPY, the hazard to honey bees and other pollinators from direct exposure during spray is well known. This has been dealt with through mitigation measures to protect pollinators through restricted use patterns that minimize direct exposure to spray or spray drift during application (see discussion of Tier-1 exposure above). The following paragraphs cover the calculation of RQ values and assessment of the potential risk to pollinators from post-application exposure.

\subsection{Estimates of Risk to Honey Bees}

Estimated risk to honey bees through dietary exposure. The geometric mean of $\mathrm{LD}_{50}$ values from dietary tests using technical CPY was less than that derived from tests with formulated product (Table 7). The geometric mean of the oral $\mathrm{LD}_{50}$ for technical CPY $\left(0.114 \mu \mathrm{g}\right.$ CPY bee $\left.{ }^{-1}\right)$ was used as a worst case in calculating RQs.

The upper limit dietary intake of CPY per day can be estimated for different life stages of honey bees based on surrogate T-REX screening values for pollen and nectar (USEPA 2012), or empirical data collected from pollen and honey and/or nectar in the field. The proposed Tier- 1 scheme includes an acute oral LOC of 0.4 for adult and larval honey bees that is compared to estimates of RQs for exposure and effects. Using the maximum screening values suggested in the USEPA's proposed risk assessment scheme for pollinators (Table 1), RQ values for oral exposure of adult and larval honey bees following sprays of CPY exceeded the LOC by over three orders of magnitude.

Tier-1 estimates of oral exposures based on T-REX are intended to be conservative, when compared to data for concentrations of CPY collected in the field. Tier-2 estimates are based on measured values of CPY in honey bee food and reflect actual use conditions. Using the monitoring data for concentrations in pollen collected from commercial beehives in the U.S. by Mullin et al. (2010) and food consumption rates established by the USEPA (USEPA 2012), the upper 95th centile dietary exposures were $0.066 \mu \mathrm{g} \mathrm{CPY} \mathrm{d}^{-1}$ for adult bees and $0.027 \mu \mathrm{g} \mathrm{CPY} \mathrm{d}^{-1}$ for larvae 
Table 12 Tier-2 risk quotients (RQs) for oral exposure of honey bees to chlorpyrifos (CPY) via pollen

\begin{tabular}{|c|c|c|c|c|}
\hline \multirow[b]{2}{*}{ Variable } & \multicolumn{2}{|c|}{ Larvae $(120 \mathrm{mg})$} & \multicolumn{2}{|c|}{ Adults (292 mg) } \\
\hline & Median & 95th centile & Median & 95th centile \\
\hline 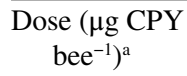 & $5.26 \times 10^{-4}$ & $2.72 \times 10^{-2}$ & $1.28 \times 10^{-3}$ & $6.61 \times 10^{-2}$ \\
\hline $\mathrm{LD}_{50}^{\mathrm{b}}$ & 0.146 & 0.146 & 0.114 & 0.114 \\
\hline $\mathrm{RQ}^{\mathrm{c}}$ & 0.004 & 0.19 & 0.011 & 0.580 \\
\hline
\end{tabular}

${ }^{\text {aReported in Table } 3}$

${ }^{\mathrm{b}}$ Technical CPY reported in Table 7 and larvae $\mathrm{LD}_{50}$ derived from Atkins and Kellum (1986)

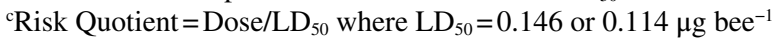

(Table 3). The estimates of oral exposure and the oral $\mathrm{LD}_{50}$ values of $0.114 \mu \mathrm{g}$ adult $^{-1}$ bee and $0.146 \mu$ larva $^{-1}$ (Atkins and Kellum 1986) provided RQ values below the LOC of 0.4 for median acute exposures. The 95 th centile exposure and larval $\mathrm{LD}_{50}$ give an RQ below the LOC, but a RQ slightly above the LOC when the adult $\mathrm{LD}_{50}$ was used (Table 12). Based on analysis of CPY in nurse bees (Table 10) fed exclusively a diet of pollen containing CPY at a concentration of $955 \mu \mathrm{g} \mathrm{kg}^{-1}$ (DeGrandi-Hoffman et al. 2013), doses were $7.5 \times 10^{-3}$ and $6.8 \times 10^{-3} \mu \mathrm{g}$ bee $^{-1}$ (93 $\mathrm{mg}$ ) for the two parallel experiments, which would be equivalent of approximately $7 \%$ of the $\mathrm{LD}_{50}$ for technical grade CPY (Table 7). The authors did not describe symptoms of toxicity in nurse bees so they were apparently unaffected.

The RQ for adults, based on the 90th centile concentration of $140.4 \mu \mathrm{g} \mathrm{kg}^{-1}$ reported by Mullin et al. (2010), is 0.36 . Therefore, dietary exposure of adult honey bees to CPY is expected to be below the LOC $>90 \%$ of the time, while exposures for larvae should be below the LOC $>95 \%$ of the time. Considering that most pollen samples (56\%) collected by Mullin et al. (2010) did not contain CPY, oral exposure to CPY should be of low risk to honey bees, particularly in terms of the protection goals of overall fitness of the colony.

Mullin et al. (2010) did not measure concentrations of pesticides in honey and no studies were found which examined concentrations of CPY in nectar. Only one study was from Uruguay reported detection of CPY in honey. The mean and maximum concentrations of CPY in honey samples that were positive for CPY (42\%) were 46 and $80 \mu \mathrm{g} \mathrm{kg}^{-1}$, respectively (Pareja et al. 2011). Using the recommended consumption rates of $120 \mathrm{mg}$ honey $\mathrm{d}^{-1}$ for larvae and $292 \mathrm{mg}$ honey $\mathrm{d}^{-1}$ for adults,

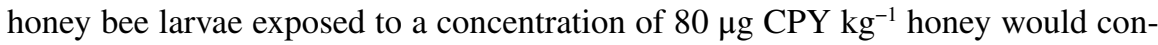
sume $0.0096 \mu \mathrm{g} \mathrm{CPY} \mathrm{d}{ }^{-1}$, whereas adults would be expected to consume $0.023 \mu \mathrm{g}$ $\mathrm{d}^{-1}$. At an $\mathrm{LD}_{50}$ of $0.114 \mu \mathrm{g}$ bee $^{-1}$, corresponding RQ values for larvae and adults would be 0.08 for larvae and 0.2 for adults. These values are below the LOC of 0.4 and suggest little risk to honey bees from acute exposure to CPY via honey.

Exposure estimates through consumption of nectar and pollen are assumed to be conservative representations of potential exposures through honey and bee bread, respectively (USEPA 2012). The estimates assume that pesticides do not degrade while honey and bee bread are stored in the hive. They also assume that rates of consumption of pollen and nectar and resulting exposures are protective of 
exposures through consumption of royal jelly and brood food, since concentrations of pesticides in food consumed by nurse bees are 2-4 orders of magnitude greater than concentrations measured in royal jelly (Davis and Shuel 1988).

Estimated risk through consumption of water. Pollinators can be exposed to CPY in drinking water from small ponds, puddles, or on foliage wet from rain or dew. Exposure from wet foliage occurs with sprayable formulations only, while exposure from puddles or small ponds occurs with both sprayable and granular formulations of CPY. Using the modified rice paddy model recommended by USEPA to provide estimates of pesticide exposure to bees through puddles in treated fields, estimated

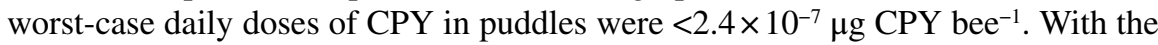
oral $\mathrm{LD}_{50}$ value of $0.114 \mu \mathrm{g}$ CPY bee ${ }^{-1}$, this provides a RQ of $2.1 \times 10^{-6}$ (Table 13), which is well below the LOC of 0.4 , indicating a de minimis risk to pollinators relative to other potential exposure routes.

Using the PRZM/EXAMS puddle 95th centile concentrations, which apply to both sprayable and granular applications of CPY, the predicted peak concentrations were much higher than the values obtained using the Tier-1 rice paddy model, since they include storm runoff events within hours after application. It is unlikely that bees would be exposed to these concentrations as storm events are rare, and such events within hours after application are even less common. Bees are not likely to go into fields to collect water, given the high humidity and availability of water around a hive after such a storm.

The model recommended by the USEPA to predict concentrations of pesticide in

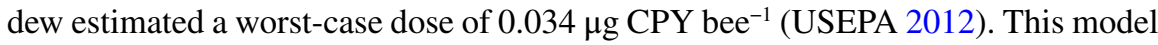
and dose also provides a RQ less than the LOC (Table 13) and suggests low risk to pollinators through consumption of contaminated dew. This scenario also applies to wet foliage from rain or irrigation as well as from dew. Residues of CPY in dew come from the leaf surface, and the concentration is determined by partition between the leaf surface and the water. The maximum potential concentration occurs when there is no runoff of rain or dew to carry material away from the leaf. As water dries, the residues partition back onto the leaf surface. Summation of exposures via food and water from Tables 12 and 13 also suggests that the risks from the combined sources would be small for most bees.

As described in the exposure section, honey bees may collect water for direct consumption, to prepare food, or to control temperature in the colony. Assuming transport of $1,250 \mathrm{mg} \mathrm{d}^{-1}$ of water to the colony from a source such as a puddle or $250 \mathrm{mg} \mathrm{d}^{-1}$ from a more temporary source such as dew, with $100 \%$ uptake of CPY from the water being carried, the modified USEPA puddle model gave an RQ well below the LOC (Table 13), but the dew model gave an RQ of 1.6. The RQ values calculated from puddle concentrations obtained using the PRZM/EXAMS model also exceeded the LOC (Table 13). These values are based on conservative approximations, and in the case of the PRZM/EXAMS predictions, have low probability of occurrence. Using the refinements in the Liqui-PARAM model, the 95th percentile RQ for collection of water from wet foliage was reduced to a level essentially the same as the LOC. The median RQ for both the OCSPP model and the Liqui-PARAM model estimates of exposure were well below the LOC (Table 13). 


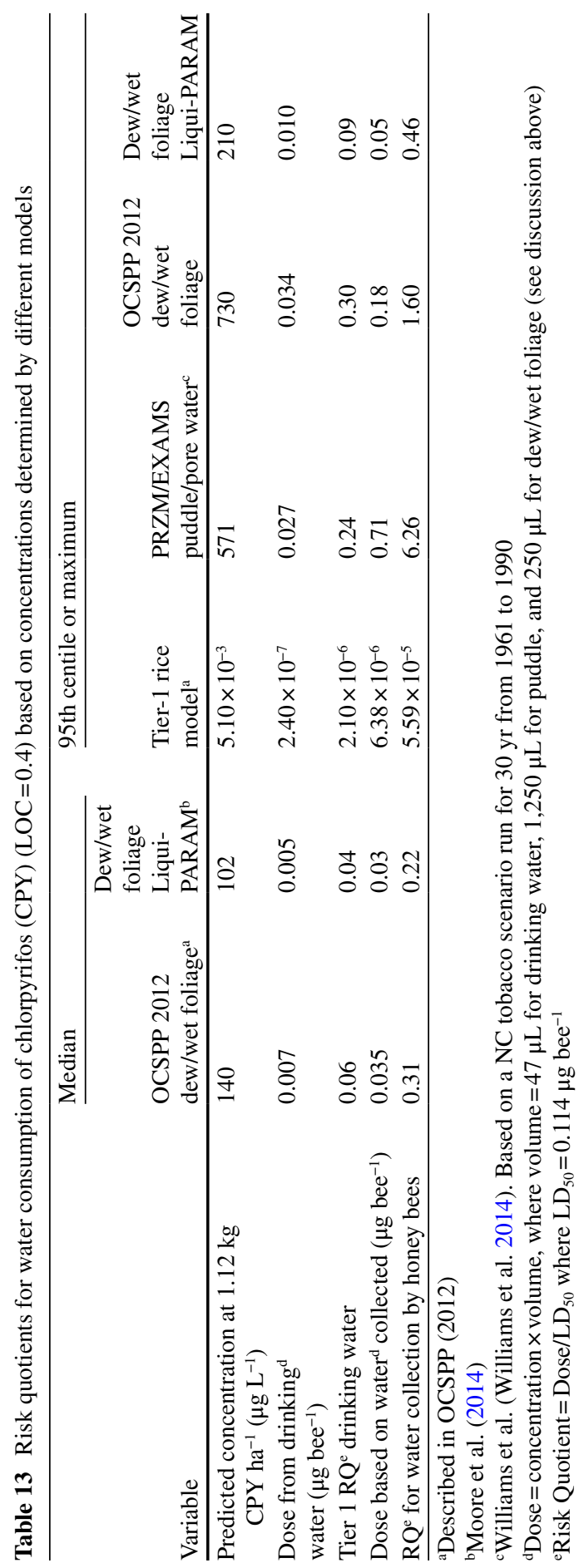


There are other reasons to expect contaminated dew or wet foliage exposure will be insignificant to honey bees. All the models used are conservative, since they are based on the assumption that honey bees will consume $100 \%$ of the water they need from a given water source, whereas in reality they can obtain 7-100\% of their required water from food (USEPA 2012). Given the short foliar half-life of CPY (Williams et al. 2014), the peak concentrations associated with the higher RQ values are present for a short time.

Assessment of aggregate risks to honey bees through semi-field and field tests. Several studies have investigated the concentrations of CPY on foliage of treated plants and this material was used in laboratory bioassays with bees (Atkins et al. 1973; Lunden et al. 1986). Their data generally showed that foliage treated with CPY at the label rate can remain lethal to honey bees, alfalfa leaf cutting bees, and alkali bees for several days after application. Residual toxicity was determined by calculating a RT25 value, which is the residue-degradation time required to bring bee mortality down to $25 \%$ or less (Lunden et al. 1986). For CPY, the RT25 was longer than $72 \mathrm{~h}$. For comparison, an RT25 of $8 \mathrm{~h}$ that was suggested as indicative of a product that poses little risk to bees (Lunden et al. 1986). Although this result from caged bioassays is expected to overestimate uptake of material from the surface and the duration of effects, it corresponds with results of multiple semi-field and field studies that indicate residual CPY on plant foliage poses a risk to honey bee survival 1-2 d after application.

With one exception, there are no guidelines for pollinator-safe post-spray periods for CPY. The exception is citrus crops in California, for which CPY must be applied from $1 \mathrm{~h}$ after sunset until $2 \mathrm{~h}$ before sunrise (see Atkins and Kellum 1993), giving a 2-h minimum post-spray interval. Assessments of effects after field applications indicate that some mortality may occur 1-2 d after application on flowering crops, and reduced foraging may persist for up to a week, but residues remaining after $7 \mathrm{~d}$ have no impact. Rapid, normal turnover of foragers in honey bees colonies and availability of alternate foraging sites should buffer out these short-term effects. There were no reports of adverse effects of CPY on honey bee brood development.

The field tests of Lunden et al. (1986) indicate that concentrations of CPY on alfalfa during flowering remain lethal to alfalfa leafcutting bees for at least $1 \mathrm{~d}$ after application, with reduced nesting observed. Because leafcutting bees are univoltine, Lunden et al. (1986) suggested applications to blooming alfalfa could have a "substantial" effect on this pollinator. Current label precautions preclude application when bees are foraging and are intended to mitigate this risk.

Assessment of risk through exposure to contaminated beeswax. A few studies have reported contamination of beeswax with CPY. Concentrations in beeswax reported by Mullin et al. (2010) were similar to amounts found in pollen. Although there can be a risk of sublethal effects through this route of exposure for some pesticides, one study found this was not the case for CPY (Wu et al. 2011). No data were available on the uptake of pesticides into larvae from contaminated wax and this is an area of uncertainty. 


\subsection{Estimates of Risk to Non-Apis Pollinators}

Studies with non-Apis pollinators. No acute direct contact or oral toxicity data $\left(\mathrm{LD}_{50}\right)$ based on laboratory tests were reported for non-Apis pollinators. In a greenhouse experiment, Gregory et al. (1992) exposed alfalfa leafcutter bees (M. rotundata) to CPY-treated alfalfa and found that mortality only occurred during the first $3 \mathrm{~d}$ after treatment. This is in agreement with semi-field and field studies with honey bees (see discussion above). Because females can only construct nests if doses of CPY on foliage are sublethal, and because the bioavailability of CPY on foliage drops rapidly, it is expected that few eggs and larvae will be exposed to hazardous amounts of CPY from nesting materials.

The only semi-field or field study with a non-Apis pollinator was performed by Gels et al. (2002). Detrimental effects were seen in bumble bee (B. impatiens) colonies exposed for 2 wk to CPY-treated clover. However, bumble bees were confined within tunnels for the duration of the entire experiment (a worst-case scenario). In an open system, effects would likely be less severe. Following label precautions to avoid application when bees are present, mowing flower heads before treatment, and weed management with herbicides are useful tactics to alleviate such hazards from applications of CPY (Gels et al. 2002).

No studies on the exposure of bee flies, Bombyliidae, and hover flies, Syrphidae, to CPY were found. Their potential for exposure is dominated by foraging at flowers since they are nonsocial insects that do not build nests, and feed only themselves. Honey bee foragers must visit more flowers, and bee behavior while on the flower leads to a much higher potential for transfer of material. Therefore, the honey bee may be considered a conservative surrogate for these taxa. Measures that are taken to protect honey bees are expected to be protective of these pollinators.

Estimated risk to non-Apis pollinators using NTAs as surrogates. Since toxicity data for CPY in NTAs is limited and the suitability of these small wasps as surrogates for wild pollinators is questionable (see above), this risk assessment was not conducted. However, Addison and Barker (2006) found that although Microctonus hyperodae, another parasitic wasp, was initially ( $1 \mathrm{~h}$ post-treatment) highly susceptible to foliage treated with CPY, no 24-h mortality was observed with 2-d old foliage at rates up to $100 \mathrm{~g} \mathrm{CPY} \mathrm{ha}^{-1}$. Bioassays such as these, where insects are confined to cages are conservative, because most flying insect pollinators do not spend much time on foliage. The risk posed by CPY is still an area of uncertainty because of the lack of data for non-Apis pollinators.

Estimated risks through exposure to contaminated soil. Although honey bees can be a good surrogate for many flying insect pollinators, ground nesting bees and mason bees can experience exposure via soil (Fig. 1), which is not encountered by honey bees. Mason bees collect soil and use it for the construction of nests, and groundnesting bees nest below the soil surface. They might dig their own burrows or they may use existing cavities built by other animals such as mice (Michener 2007). CPY is toxic to soil dwelling insects and is used in the management of soil dwelling pests. European chafer grubs (Amphimallon majalis) and leatherjackets (Tipula spp.) are known to have suffered significant mortality at field-relevant CPY soil concentrations 
(Clements and Bale 1988; Tashiro and Kuhr 1978). However, the potential for use of these data to provide a worst-case estimate of CPY exposure to ground nesting bees through soil is limited, because it is unclear how much of this mortality was due to contact with soil, versus ingestion of CPY on plant roots. Different behavioral and physiological differences between soil pests and ground nesting pollinators might influence uptake of CPY from soil.

Several factors would likely reduce the risk of CPY to ground nesting bees. The tendency of CPY to adsorb to soil surfaces reduces bioavailability of CPY in most soil environments (Racke 1993), but the time for toxicity to drop below levels that cause mortality or sublethal effects on ground nesting pollinators is unknown. The dearth of studies on nesting of bees within agriculture fields (Julier and Roulston 2009; Kim et al. 2006; Williams et al. 2010; Wuellner 1999) suggests that most species nest outside cultivated fields where the risk of exposure is low. Many of these are solitary bees that forage specifically on non-agricultural plants and nest in nonagricultural soil (Willmer 2011). Nonetheless there are some important pollinators including squash bees (Peponapis sp.) that nest within crops (Julier and Roulston 2009), where the potential for exposure to CPY is much higher. Although CPY is not registered for use on squash or cucurbit crops pollinated by squash bees, there may be other bees that do nest in crops treated with CPY.

Exposure might also vary depending on the architecture of cells within the nest. Although cells of some nests are unlined excavations into the soil, those of other species are lined with a cellulose- or wax-like material (Michener 2007) that possibly provides a barrier from direct contact with soil. Even without a lining, the potential for transfer of residues from soil to the insect during entry and exit from a nest is much lower than when the insect is digging through the soil. Immature life stages are expected to be less exposed than adults. For example, bumble bees usually nest underground, but larvae develop within their own cocoons. Eggs and larvae cannot actually contact the soil at all until late development and adult emergence (Michener 2007), and their dietary exposure is limited to the levels that can be successfully brought to the hive by adult foragers. Contact with freshly contaminated soil is not likely to be a major contribution to aggregate CPY exposure for ground-nesting bees, but it has not been characterized or quantified and remains an area of uncertainty.

No studies were found, in which soil was collected from mason bee (Osmia spp.) nests from within areas exposed to CPY. Exposure via soil in this group is limited by the rapid degradation and limited bioavailability of CYP on soil. As with other nesting bees, CPY exposure of immature life stages is limited to concentrations that are collected by adults, and because larvae do not emerge until long after the nest is built, CPY residues on this soil would be negligible.

\subsection{Strengths and Uncertainties}

The current assessment delineated potential exposure pathways of CPY to pollinators in detail. Sufficient exposure and effects data relevant to honey bees were available and permitted a satisfactory characterization of the risk of CPY to them. 
Data on non-Apis bees was scant, and data available for NTA as surrogates for non-Apis pollinators was not usable in the risk assessment. However, in many cases the honey bee is a suitable surrogate for exposure and effects in other pollinating insects. Since all insect pollinators have in common certain aspects of their behavior, biology, and ecology, worst-case exposures for honey bees should generally be protective of non-Apis bees. However, there are a number of biological and ecological characteristics of these taxa that can influence risk. Some of these have been described previously and relate to: the role of the queen in founding nests in the spring; increased susceptibility due to smaller colony nest size (i.e., less redundancy); the smaller size of some of non-Apis bees that leads to greater potential for exposure (i.e., greater surface area:volume ratio); the smaller foraging range; and the location and construction of nests (EFSA 2012; Thompson and Hunt 1999).

We identified several data gaps and areas of uncertainty in our assessment of CPY on pollinators. Below, we summarize key research topics that deserve more research attention, many of which are relevant to other insecticides:

- Given the increasing recognition of the significant role that wild bees have in agricultural and natural ecosystems (Garibaldi et al. 2013), more data are needed on non-Apis species to accurately evaluate the risk of CPY to these taxa as part of higher tier testing.

- More information on sublethal effects of CPY on pollinators is needed, in view of the recent increased focus on behavioral effects such as navigation to and from the hive. However, accepted guidelines for sublethal tests are also required.

- The stability and rate of degradation of CPY residues in nectar, pollen, and bees wax should be determined. Area-wide concentrations have been reported in monitoring studies, but the concentrations of CPY in nectar and pollen over time, following a defined field application, have not been quantified. Concentrations are expected to be lower on pollen and nectar than foliage for non-systemic insecticides like CPY, but the Tier-1 assessment models assume the same levels are present in all parts of the plant. In addition, depending on floral phenology, pollen present at the time of application will likely be available or attractive to foraging pollinators for only a few days after application. Quantification of concentrations of CPY in pollen and nectar over time after application would help to refine the risk assessment and facilitate testing in the laboratory with environmentally relevant concentrations and routes of exposure.

- How CPY partitions and transfers between wax and bee brood or the food stored in wax cells is unknown. It is possible that wax represents a sink for CPY in the colony and that the residues are not bio-available when present at the concentrations that have been reported in wax. Although there can be a risk of sublethal effects from residue in wax for some pesticides, this was not the case for CPY (Wu et al. 2011).

- Partitioning of CPY from wax, in the range of concentrations that have been reported, into the airspace of a colony should be quantified. The physical properties of CPY and its strong propensity to partition into nonpolar substances makes 
it unlikely that volatility from wax in a honey bee hive is a significant exposure pathway. Partitioning of vapor from air into wax is more likely.

- The transfer of CPY from soil or foliage during nest construction is expected to be minor or insignificant, except in the first few hours after application. However, tests on the transfer of CPY from nesting materials on a variety of species is needed to confirm that this route of exposure is negligible, and it may be that the exposure is so low that differences in species sensitivity are unimportant. As this route of exposure is one of the key differences between the exposure pathways encountered by foraging honey bees and many solitary pollinators, new research results would clarify the usefulness of honey bees as a surrogate for other species.

- The significance of extra-floral nectaries as a food source and potential route of exposure appears to be minor, but has not been quantified.

\section{Summary}

CPY is an organophosphorus insecticide that is widely used in North American agriculture. It is non-systemic, comes in several sprayable and granular formulations, and is used on a number of high-acreage crops on which pollinators can forage, including tree fruits, alfalfa, corn, sunflower, and almonds. Bees (Apoidea) are the most important pollinators of agricultural crops in North America and were the main pollinators of interest in this risk assessment.

The conceptual model identified a number of potential exposure pathways for pollinators, some more significant than others. CPY is classified as being highly toxic to honey bees by direct contact exposure. However, label precautions and good agricultural practices prohibit application of CPY when bees are flying and/or when flowering crops or weeds are present in the treatment area. Therefore, the risk of CPY to pollinators through direct contact exposure should be small. The main hazards for primary exposure for honey bees are dietary and contact exposure from flowers that were sprayed during application and remain available to bees after application. The main pathways for potential secondary exposure to CPY is through pollen and nectar brought to the hive by forager bees and the sublethal body burden of CPY carried on forager bees. Foraging for other materials, including water or propolis, does not appear to be an important exposure route. Since adult forager honey bees are most exposed, their protection from exposure via pollen, honey, and contact with plant surfaces is expected to be protective of other life stages and castes of honey bees.

Tier-1 approaches to estimate oral exposure to CPY through pollen and nectar/ honey, the principle food sources for honey bees, suggested that CPY poses a risk to honey bees through consumption of pollen and nectar. However, a Tier- 2 assessment of concentrations reported in pollen and honey from monitoring work in North America indicated there is little risk of acute toxicity from CPY through consumption of these food sources. 
Several models were also used to estimate upper-limit exposure of honey bees to CPY through consumption of water from puddles or dew. All models suggest that the risk of CPY is below the LOC for this pathway. Laboratory experiments with field-treated foliage, and semi-field and field tests with honey bees, bumble bees, and alfalfa leafcutting bees indicate that exposure to foliage, pollen and/or nectar is hazardous to bees up to $3 \mathrm{~d}$ after application of CPY to a crop. Pollinators exposed to foliage, pollen or nectar after this time should be minimally affected.

Several data gaps and areas of uncertainty were identified, which apply to CPY and other foliar insecticides. These primarily concern the lack of exposure and toxicological data on non-Apis pollinators. Overall, the rarity of reported bee kill incidents involving CPY indicates that compliance with the label precautions and good agricultural practice with the product is the norm in North American agriculture. Overall, we concluded that, provided label directions and good agricultural practices are followed, the use of CPY in agriculture in North America does not present an unacceptable risk to honeybees.

Acknowledgements We thank Dow AgroSciences, LLC for their support of this study, in particular Nick Poletika for assistance in gathering technical information, and Mark Miles for discussion on assessments using non-target arthropods. We thank Dwayne R.J. Moore for providing a model used in estimation of CPY in dew, Marty Williams for providing data on concentrations in puddles, and anonymous reviewers for useful comments and suggestions. Prof. Giesy was supported by the Canada Research Chair program, a Visiting Distinguished Professorship in the Department of Biology and Chemistry and State Key Laboratory in Marine Pollution, City University of Hong Kong, the 2012 "High Level Foreign Experts" (\#GDW20123200120) program, funded by the State Administration of Foreign Experts Affairs, the P.R. China to Nanjing University and the Einstein Professor Program of the Chinese Academy of Sciences. Funding for this project was provided by Dow AgroSciences.

Open Access This article is distributed under the terms of the Creative Commons Attribution Noncommercial License, which permits any noncommercial use, distribution, and reproduction in any medium, provided the original author(s) and source are credited.

\section{References}

Addison PJ, Barker GM (2006) Effect of various pesticides on the non-target species Microctonus hyperodae, a biological control agent of Listronotus bonariensis. Entomol Exp Appl 119:71-79

Ahmed S, Ahmad M (2006) Note: toxicity of some insecticides on Bracon hebetor under laboratory conditions. Phytoparasitica 34:401-404

Alix A, Lewis G (2010) Guidance for the assessment of risks to bees from the use of plant protection products under the framework of Council Directive 91/414 and Regulation 1107/2009. EPPO Bull 40:196-203

Anonymous (1986) Bee-toxicological test of Dursban 4 (EF-747). Station for Wildlife and Nature Conservancy Facankert. 29 pp

Atkins EL, Greywood EA, Macdonald RL (1973) Effects of pesticides on agriculture. University of California Riverside, Riverside, CA, USA. Report No. 1499

Atkins EL, Kellum D (1986) Comparative morphogenic and toxicity studies on the effect of pesticides on honeybee brood. J Apic Res 25:242-255 
Atkins EL, Kellum D (1993) A compilation of data concerning the effects of LORSBAN applications on honey bees. University of California, Riverside, CA, Unpublished Report

Atkins LE (1975) Injury to honey bees by poisoning. In: Veatch E (ed) The hive and the honey bee. Dadant \& Sons, Hamilton, IL, pp 663-696

Ayers GS, Harman JR (1992) Bee forage of North America and the potential for planting for bees. In: Graham JM (ed) The hive and the honey bee, revised edition. Dadant \& Sons, Hamilton, IL, pp 437-535

Bakker F (2000) Effects of Dursban 75 WG on honeybees, Apis mellifera L., when applied to Phacelia tanacetifolia 1, 3, 5, 7 and 17 days before exposure, determined in a cage test. Dow AgroSciences, Indianapolis, IN, Unpublished Report

Bakker F, Calis J (2003) A semi-field approach to testing effects of fresh or aged pesticide residues on bees in multiple-rate test designs. Bull Insectol 56:97-102

Barmaz S, Potts SG, Vighi M (2010) A novel method for assessing risks to pollinators from plant protection products using honeybees as a model species. Ecotoxicol 19:1347-1359

Bell G (1993) EF 1042 (Dursban 480) acute toxicity to honey bees (Apis mellifera). DowElanco Europe, Letcombe Regis, Unpublished Report

Bell G (1996) EF-1315: acute oral and contact toxicity to honey bees (Apis mellifera). DowElanco Europe, Letcombe Regis, p 28, Unpublished Report

Berger LA, Vaissiere BE, Moffett JO, Merritt SJ (1988) Bombus spp. (Hymenoptera: Apidae) as pollinators of male-sterile upland cotton on the Texas High Plains. Environ Entomol 17:789-794

Buck NA, Estesen BJ, Ware GW (1980) Dislodgable insecticide residues on cotton foliage: Fenvalarate, permethrin, sulprofos, chlorpyrifos, methyl parathion, EPN, oxamyl, and profenofos. Bull Environ Contam Toxicol 24:283-288

Butler CG (1975) The honey bee colony life history. In: Veatch E (ed) The hive and the honey bee. Dadant \& Sons, Hamilton, IL, pp 39-74

Calderone NW (2012) Insect pollinated crops, insect pollinators and US agriculture: Trend analysis of aggregate data for the period 1992-2009. PLoS ONE 7:e37235

Candolfi MP, Barrett KL, Campbell PJ, Forster R, Grandy N, Huet M-C, Lewis G, Oomen PA, Schmuck R, Vogt H (2001) Guidance document on regulatory testing and risk assessment procedures for plant protection products with non-target arthropods. Society of Environmental Toxicology and Chemistry Europe, Brussels

Carman H (2011) The estimated impact of bee colony collapse disorder on almond pollination fees. ARE Update 14:9-11

Carrasco-Letelier L, Mendoza-Spina Y, Branchiccela MB (2012) Acute contact toxicity test of insecticides (Cipermetrina 25, Lorsban 48E, Thionex 35) on honeybees in the southwestern zone of Uruguay. Chemosphere 88:439-444

Chambers JE, Redwood WT, Trevathan CA (1983) Disposition of metabolism of ${ }^{14} \mathrm{C}$-chlorpyrifos in the black imported fire ant, Solenopsis richteri Forel. Pestic Biochem Physiol 19:115-121

Chauzat M, Martel A, Cougoule N, Porta P, Lachaize J, Zeggane S, Aubert M, Carpentier P, Faucon J (2011) An assessment of honeybee colony matrices, Apis mellifera (Hymenoptera: Apidae) to monitor pesticide presence in continental France. Environ Toxicol Chem 30:103-111

Chen JL (1994) Volatility control for foliage-applied chlorpyrifos by using controlled release emulsions. J Control Release 29:83-95

Choudhary A, Sharma DC (2008) Pesticide residues in honey samples from Himachal Pradesh (India). Bull Environ Contam Toxicol 80:417-422

Clements RO, Bale JS (1988) The short-term effects on birds and mammals of the use of chlorpyrifos to control leatherjackets in grassland. Ann Appl Biol 112:41-47

Clinch PG (1972) Chlorpyrifos found to be highly toxic to honey bees. Agricultural DepartmentWallaceville Animal Research Centre, Wallaceville, New Zealand, 19903

Cutler GC (2013) Pesticides in honey bee hives in the maritime provinces: residue levels and interactions with Varroa Mites and Nosema in colony stress. Dalhousie University, Truro, NS, Unpublished Report 
Davis AR, Shuel RW (1988) Distribution of ${ }^{14} \mathrm{C}$-labeled carbofuran and dimethoate in royal jelly, queen larvae and nurse honeybees. Apidologie 19:37-50

Davis BNK, Williams CT (1990) Buffer zone widths for honeybees from ground and aerial spraying of insecticides. Environ Pollut 63:247-259

DeGrandi-Hoffman G, Chen Y, Simonds R (2013) The effects of pesticides on queen rearing and virus titers in honey bees (Apis mellifera $\mathrm{L}$.). Insects 4:71-89

Desneux N, Rafalimanana H, Kaiser L (2004) Dose-response relationship in lethal and behavioural effects of different insecticides on the parasitic wasp Aphidius ervi. Chemosphere 54:619-627

Desneux N, Decourtye A, Delpuech J-M (2007) The sublethal effects of pesticides on beneficial arthropods. Annu Rev Entomol 52:81-106

Dietz A (1975) Nutrition of the adult honey bee. In: Veatch E (ed) The hive and the honey bee. Dadant \& Sons, Hamilton, IL, pp 125-126

Donahue RL, Miller RW, Shickluna JC (1983) Soils, an introduction to soils and plant growth. Prentice Hall, Englewood Cliffs, NJ, 768 pp

EFSA (2012) EFSA panel on plant protection products and their residues (PPR); scientific opinion on the science behind the development of a risk assessment of plant protection products on bees (Apis mellifera, Bombus spp. and solitary bees). EFSA J 10:2668

Fischer D, Moriarty T (2011) Pesticide risk assessment for pollinators: summary of a SETAC Pellston Workshop. Society of Environmental Toxicology and Chemistry, Pensacola, FL

Fletcher JS, Nellessen JE, Pfleeger TG (1994) Literature review and evaluation of the EPA foodchain (Kenaga) nomogram, an instrument for estimating pesticide residues on plants. Environ Toxicol Chem 13:1383-1391

Garibaldi LA, Steffan-Dewenter I, Winfree R, Aizen MA, Bommarco R, Cunningham SA, Kremen C, Carvalheiro LG, Harder LD, Afik O, Bartomeus I, Benjamin F, Boreux V, Cariveau D, Chacoff NP, Dudenhöffer JH, Freitas BM, Ghazoul J, Greenleaf S, Hipólito J, Holzschuh A, Howlett B, Isaacs R, Javorek SK, Kennedy CM, Krewenka KM, Krishnan S, Mandelik Y, Mayfield MM, Motzke I, Munyuli T, Nault BA, Otieno M, Petersen J, Pisanty G, Potts SG, Rader R, Ricketts TH, Rundlöf M, Seymour CL, Schüepp C, Szentgyörgyi H, Taki H, Tscharntke T, Vergara CH, Viana BF, Wanger TC, Westphal C, Williams N, Klein AM (2013) Wild pollinators enhance fruit set of crops regardless of honey bee abundance. Science 339:1608-1611

Gary NE (1975) Activities and behavior of honey bees. In: Veatch E (ed) The hive and the honey bee. Dadant \& Sons, Hamilton, IL , pp 185-264

Gels JA, Held DW, Potter DA (2002) Hazards of insecticides to the bumble bees Bombus impatiens (Hymenoptera: Apidae) foraging on flowering white clover in turf. J Econ Entomol 95:722-728

Ghini S, Fernández M, Picó Y, Marín R, Fini F, Mañes J, Girotti S (2004) Occurrence and distribution of pesticides in the province of Bologna, Italy, using honeybees as bioindicators. Arch Environ Contam Toxicol 47:479-488

Giesy JP, Solomon KR, Coats JR, Dixon KR, Giddings JM, Kenaga EE (1999) Chlorpyrifos: ecological risk assessment in North American aquatic environments. Rev Environ Contam Toxicol 160:1-129

Goh KS, Edmiston S, Maddy KT, Meinders DD (1986) Dissipation of dislodgeable residues of chlorpyrifos and dichlorvos on turf. Bull Environ Contam Toxicol 37:27-32

Gomez LE (2009) Use and benefits of chlorpyrifos in US agriculture. Dow AgroSciences, Indianapolis, IN, Unpublished Report

Gregoric A, Ellis JD (2011) Cell death localization in situ in laboratory reared honey bee (Apis mellifera L.) larvae treated with pesticides. Pestic Biochem Physiol 99:200-207

Gregory DA, Johnson DL, Thompson BH, Richards KW (1992) Laboratory evaluation of the effects of carbaryl and chlorpyrifos baits and sprays on alfalfa leafcutting bees (Megachile rotundata $\mathrm{F}$.). J Agric Entomol 9:109-115

Hahne R (2000) Lorsban $50 \mathrm{~W}$ : acute oral toxicity test with the honeybee, Apis mellifera. Dow AgroSciences, Indianapolis, IN, Unpublished Report 
Hurto KA, Prinster MG (1993) Dissipation of foliar dislodgeable residues of chlorpyrifos, DCPA, diazinon, isofenphos, and pendimethalin. In: Racke KD, Leslie AR (eds) Fate and significance of pesticides in urban environments, vol ACS, Symposium Series 522. American Chemical Society, Washington, DC, pp 86-99

Iwata T, O’Neal JR, Barkley JH, Dinoff TM, Dusch E (1983) Chlorpyrifos applied to California citrus: residue levels on foliage and on and in fruit. J Agric Food Chem 31:603-610

Johnson RM, Ellis MD, Mullin CA, Frazier M (2010) Pesticides and honey bee toxicity-USA. Apidologie 41:312-331

Julier HE, Roulston TH (2009) Wild bee abundance and pollination service in cultivated pumpkins: farm management, nesting behavior and landscape effects. $\mathrm{J}$ Econ Entomol 102:563-573

Kevan PG, Clark EA, Thomas VG (1990) Pollination: a crucial ecological and mutualistic link in agro-forestry and sustainable agriculture. Proc Entomol Soc Ont 121:43-48

Kevan PG (1999) Pollinators as bioindicators of the state of the environment; species, activity and diversity. Agr Ecosyst Environ 74:373-393

Kim J, Williams N, Kremen C (2006) Effects of cultivation and proximity to natural habitat on ground-nesting native bees in California sunflower fields. J Kans Entomol Soc 79:309-320

Klein A-M, Vaissière BE, Cane JH, Steffan-Dewenter I, Cunningham SA, Kremen C, Tscharntke $\mathrm{T}$ (2007) Importance of pollinators in changing landscapes for world crops. Proc R Soc B Biol Sci 274:303-313

Kwon H, Lehotay SJ, Geis-Asteggiante L (2012) Variability of matrix effects in liquid and gas chromatography-mass spectrometry analysis of pesticide residues after QuEChERS sample preparation of different food crops. J Chromatogr A 1270:235-245

Lunden JD, Mayer DF, Johansen CA, Shanks CH, Eves JD (1986) Effects of chlorpyrifos insecticide on pollinators. Am Bee J 126:441-444

Mackay D, Giesy JP, Solomon KR (2014) Fate in the environment and long-range atmospheric transport of the organophosphorus insecticide, chlorpyrifos and its oxon. Rev Environ Contam Toxicol 231:35-76

Mansour SA, Al-Jalili MK (1985) Determination of residues of some insecticides in clover flowers: a bioassay method using honeybee adults. J Apic Res 24:195-198

Mayer DF, Johansen CA (1983) Occurrence of honey bee (Hymenoptera: Apidae) poisoning in Eastern Washington. Environ Entomol 12:317-320

Michener CD (2007) The bees of the world. John Hopkins University Press, Baltimore, MD, 913 pp

Miles MJ, Alix A (2012) Assessing the comparative risk of plant protection products to honey bees, non-target arthropods and non-Apis bees. In: Oomen P, Thompson H (eds) Hazards of Pesticides to Bees-11th International Symposium of the ICP-Bee Protection Group, 2011, vol 437. Julius-Kühn-Archiv, Wageningen, pp 30-38

Moore DRJ, Teed RS, Greer C, Solomon KR, Giesy JP (2014) Refined avian risk assessment for chlorpyrifos in the United States. Rev Environ Contam Toxicol 231:163-217

Morse RA, Calderone NW (2000) The value of honey bees as pollinators of U.S. crops in 2000. Bee Cult (March 2000):2-15.

Mullin CA, Frazier M, Frazier JL, Ashcraft S, Simonds R, vanEngelsdorp D, Pettis JS (2010) High levels of miticides and agrochemicals in North American apiaries: implications for honey bee health. Plos One 5:e9754

NAS (2007) Status of pollinators in North America. The National Academies Press, Washington, DC, $322 \mathrm{pp}$

Pareja L, Colazzo M, Perez-Parada A, Niell S, Carrasco-Letelier L, Besil N, Cesio MV, Heinzen H (2011) Detection of pesticides in active and depopulated beehives in Uruguay. Int J Environ Res Pub Hlth 8:3844-3858

Porrini C, Sabatini AG, Girotti S, Fini F, Monaco L, Celli G, Bortolotti L, Ghini S (2003) The death of honey bees and environmental pollution by pesticides: the honey bees as biological indicators. Bull Insectol 56:147-152 
Putnam RA, Nelson JO, Clark JM (2003) The persistence and degradation of chlorothalonil and chlorpyrifos in a cranberry bog. J Agric Food Chem 51:170-176

Racke KD (1993) Environmental fate of chlorpyrifos. Rev Environ Contam Toxicol 131:1-154

Raven PH, Evert RF, Eichhorn SE (1992) Biology of plants. Worth Publishers, New York, NY, 800 pp

Rhodes J (2002) Cotton pollination by honey bees. Aust J Exp Agric 42:513-518

Rissato SR, Galhiane MS, de Almeida MV,MG, Apon BM (2007) Multiresidue determination of pesticides in honey samples by gas chromatography-mass spectrometry and application in environmental contamination. Food Chem 101:1719-1726

Rortais A, Arnold G, Halm M-P, Touffet-Briens F (2005) Modes of honeybees exposure to systemic insecticides: estimated amounts of contaminated pollen and nectar consumed by different categories of bees. Apidologie 36:71-83

Schmitzer S (2008) Effects of GF-2153 (acute contact and oral) on honey bees (Apis mellifera L.) in the laboratory. Dow AgroSciences, Indianapolis, IN, Unpublished Report

Sears MK, Bowhey C, Braun H, Stephenson GR (1987) Dislodgeable residues and persistence of diazinon, chlorpyrifos and isofenphos following their application to turfgrass. Pestic Sci 20:223-231

Serra-Bonvehí J, Orantes-Bermejo J (2010) Acaricides and their residues in Spanish commercial beeswax. Pest Manag Sci 66:1230-1235

Shafiq ur R (2009) Evaluation of malonaldialdehyde as an index of chlorpyriphos insecticide exposure in Apis mellifera: Ameliorating role of melatonin and $\alpha$-tocopherol against oxidative stress. Toxicol Environ Chem 91:1135-1148

Snodgrass RE (1975) The anatomy of the honey bee. In: Veatch E (ed) The hive and the honey bee. Dadant \& Sons, Hamilton, IL, pp 75-124

Solomon KR, Giesy JP, Kendall RJ, Best LB, Coats JR, Dixon KR, Hooper MJ, Kenaga EE, McMurry ST (2001) Chlorpyrifos: ecotoxicological risk assessment for birds and mammals in corn agroecosystems. Human Ecol Risk Assess 7:497-632

Solomon KR, Williams WM, Mackay D, Purdy J, Giddings JM, Giesy JP (2014) Properties and uses of chlorpyrifos in the United States. Rev Environ Contam Toxicol 231:13-34

Somerville D (2005) Fat bees, skinny bees: a manual on honey bee nutrition for beekeepers-A report for the Rural Industries Research and Development Corporation of Australia. NSW Department of Primary Industries, Goulburn, NSW, Australia

Stevenson JH (1978) The acute toxicity of unformulated pesticides to worker honey bees (Apis mellifera L.). Plant Pathol 27:38-40

Tashiro H, Kuhr RJ (1978) Some factors influencing the toxicity of soil applications of chlorpyrifos and diazinon to European chafer grubs. J Econ Entomol 71:904-907

Tashiro H (1987) Turfgrass insects of the United States and Canada. Comstock Pub. Associates, Ithaca, NY, $391 \mathrm{pp}$

Tetreault GE (1985) Metabolism of carbaryl, chlorpyrifos, DDT, and parathion in the European corn borer: Effects of microsporidiosis on toxicity, Department of Entomology. University of Illinois, Urbana-Champaign, IL, $79 \mathrm{pp}$

Thompson HM, Hunt LV (1999) Extrapolating from honeybees to bumblebees in pesticide risk assessment. Ecotoxicol 8:147-166

Thompson HM, Maus C (2007) The relevance of sublethal effects in honey bee testing for pesticide risk assessment. Pest Manag Sci 63:1058-1061

Tunink A (2010) Chlorpyrifos-oxon: determination of hydrolysis as a function of $\mathrm{pH}$. DowAgroScience, Indianapolis, IN, Unpublished Report

USEPA (1988) Nontarget insect data requirements, 40 CFR 158.590. http://www.gpo.gov/fdsys/ pkg/CFR-2004-title40-vol22/pdf/CFR-2004-title40-vol22-sec158-590.pdf. Accessed Dec 2012

USEPA (1998) Guidelines for ecological risk assessment. Fed Reg 63:26846-26924

USEPA (2005) Reregistration eligibility science chapter for carbofuran. Environmental fate and effects chapter. Environmental risk assessment and human drinking water exposure assessment. United States Environmental Protection Agency, Office of Pesticide Programs, Washington, D.C. 
USEPA (2012) White paper in support of the proposed risk assessment process for bees. United States Environmental Protection Agency Chemical Safety and Pollution Prevention, Office of Pesticide Programs, Environmental Fate and Effects Division. Washington, DC

USEPA (2013) United States Environmental Protection Agency, Office of Pesticide Programs Ecological Incident Information System (EIIS) Database. Queried on 11 April 2013

Ware GW, Estesen BJ, Buck NA (1980) Dislodgable insecticide residues on cotton foliage: acephate, AC 222,705, EPN, fenvalerate, methomyl, methyl parathion, permethrin, and thiodicarb. Bull Environ Contam Toxicol 25:608-615

Wass MN, Branson DR (1970) Comparative metabolism of insecticides. II. The fate of O, O-diethyl O-(3,5,6-trichloro-2-pyridyl) phosphorothioate in Madeira cockroaches. DowElanco, Indianapolis, IN, Unpublished Report

Williams WM, Giesy JP, Solomon KR (2014) Exposures of aquatic organisms to the organophosphorus insecticide, chlorpyrifos resulting from use in the United States. Rev Environ Contam Toxicol 231:

Williams NM, Crone EE, Roulston TH, Minckley RL, Packer L, Potts SG (2010) Ecological and life-history traits predict bee species responses to environmental disturbances. Biol Conserv 143:2280-2291

Willmer P (2011) Pollination and floral ecology. Princeton University Press, Princeton, NJ, 828 pp

Winfree R, Aguilar R, Vázquez DP, Lebuhn G, Aizen MA (2009) A meta-analysis of bees' responses to anthropogenic disturbance. Ecol 90:2068-2076

Winston ML (1987) The biology of the honey bee. Harvard University Press, Cambridge, MA

Wu JY, Anelli CM, Sheppard WS (2011) Sub-lethal effects of pesticide residues in brood comb on worker honey bee (Apis mellifera) development and longevity. PlosONE 6:e14720

Wuellner CT (1999) Nest site preference and success in a gregarious, ground-nesting bee Dieunomia triangulifera. Ecol Entomol 24:471-479 